Review

\title{
Nanoparticles Biosynthesized by Fungi and Yeast: A Review of Their Preparation, Properties, and Medical Applications
}

\author{
Amin Boroumand Moghaddam ${ }^{1}$, Farideh Namvar ${ }^{2,3, *}$, Mona Moniri ${ }^{1}$, Paridah Md. Tahir ${ }^{2}$, \\ Susan Azizi ${ }^{1}$ and Rosfarizan Mohamad ${ }^{1,2, *}$
}

1 Department of Bioprocess Technology, Faculty of Biotechnology and Biomolecular Sciences, Universiti Putra Malaysia, Serdang, Selangor 43400 UPM, Malaysia;

E-Mails: amin.broomandm@yahoo.com (A.B.M.); Mona_moniri6@yahoo.com (M.M.); azisusan@gmail.com (S.A.)

2 Institute of Tropical Forestry and Forest Products (INTROP), Universiti Putra Malaysia, Serdang, Selangor 43400 UPM, Malaysia; E-Mail: parida.introp@gmail.com

3 Research Center for Animal Development Applied Biology \& Department of Medicine, Mashhad Branch, Islamic Azad University, Mashhad 91735, Iran

* Authors to whom correspondence should be addressed;

E-Mails: Farideh.namvar@putra.upm.my (F.N.); farizanmohd@gmail.com (R.M.); Tel.: +60-17-399-6005 (F.N.); Fax: +60-3-8946-6916 (F.N.).

Academic Editor: Derek J. McPhee

Received: 17 June 2015 / Accepted: 18 August 2015 / Published: 11 September 2015

\begin{abstract}
In the field of nanotechnology, the use of various biological units instead of toxic chemicals for the reduction and stabilization of nanoparticles, has received extensive attention. Among the many possible bio resources, biologically active products from fungi and yeast represent excellent scaffolds for this purpose. Since fungi and yeast are very effective secretors of extracellular enzymes and number of species grow fast and therefore culturing and keeping them in the laboratory are very simple. They are able to produce metal nanoparticles and nanostructure via reducing enzyme intracellularly or extracellularly. The focus of this review is the application of fungi and yeast in the green synthesis of inorganic nanoparticles. Meanwhile the domain of biosynthesized nanoparticles is somewhat novel; the innovative uses in nano medicine in different areas including the delivery of drug, cancer therapy, antibacterial, biosensors, and MRI and medical imaging are reviewed. The proposed signaling pathways of nanoparticles induced apoptosis in cancerous cells and anti-angiogenesis effects also are reviewed. In this article, we provide a short summary of the present study universally on the
\end{abstract}


utilization of eukaryotes like yeast and fungi in the biosynthesis of nanoparticles (NPs) and their uses.

Keywords: nanoparticle; fungi; yeast; apoptosis; anti-angiogenesis

\section{Introduction}

Nanotechnology is an innovative field which influences all aspects of human's life [1,2]. Nanoparticles (NPs) are applied in a variety of majors such as "nanomedicine", they are paid so much attention in this field [3].Nanoparticles can be widely classified into two groups of organic and inorganic ones. While organic nanoparticles consist of carbon nanoparticles, a number of the inorganic nanoparticles contain magnetic nanoparticles, the noble metal nanoparticles (like gold and silver) and semi-conductor nanoparticles (like titanium oxide and zinc oxide). Since inorganic nanoparticles are recently utilized as catalysts [4], semiconductors [5], optical devices, biosensors [6], encapsulation of drugs, and contrast agents, to name a few, their production has attracted great attention. In addition, as inorganic biomass nanoparticles i.e., of noble metal nanoparticles (gold and silver) catering for better-quality material properties with functional flexibility, there is an increasing interest in their formation.

The most significant biomedical agents are considered as metallic nanoparticles. To synthesize the nanoparticles, silver, aluminum, gold, zinc, carbon, titanium, palladium, iron, fullerenes and copper have been regularly utilized. The Au-NPs were used in the 16th century, for both medical and staining aims [7]. As such, the development of environmentally friendly procedures via green synthesis and further biological methods is highly needed.

A number of scientists have developed an assortment of chemical and physical methods to attain such geometries which can be utilized in diverse applications. Photolithography [8], electron, ion beam lithography [9], dip pen lithography [10], micro contact printing, electrochemical synthesis and nano imprint lithography are considered as new techniques for achieving such sole geometries in nanomaterial's. The geometries can be achieved by employing the physical approach [11]. The chemical processes begin with decreasing the metal ions to metal atoms which is pursued by controlled mass of atoms [12].

The majority of the chemical and physical techniques employed for the synthesis of nanoparticles are very costly. Moreover, it contains the application of poisonous and dangerous chemicals responsible for different biological hazards (Scheme 1). This matter increases the necessity of developing environmentally friendly procedure by means of green synthesis and extra biological methods. In this article, we provide a summary of the present study universally on the implication of microorganisms like yeast and fungi in the biosynthesis of inorganic nanoparticles, their proposed signaling pathways and uses.

\section{Biological Synthesis of Nanoparticles}

For the synthesis of metallic nanoparticles, living extracts have been utilized by researchers. They followed easy processes such as the procedures of reducing the metal ions. In doing so, they made use of biomass extracts as a basis of extracellular or intracellular reductants. 


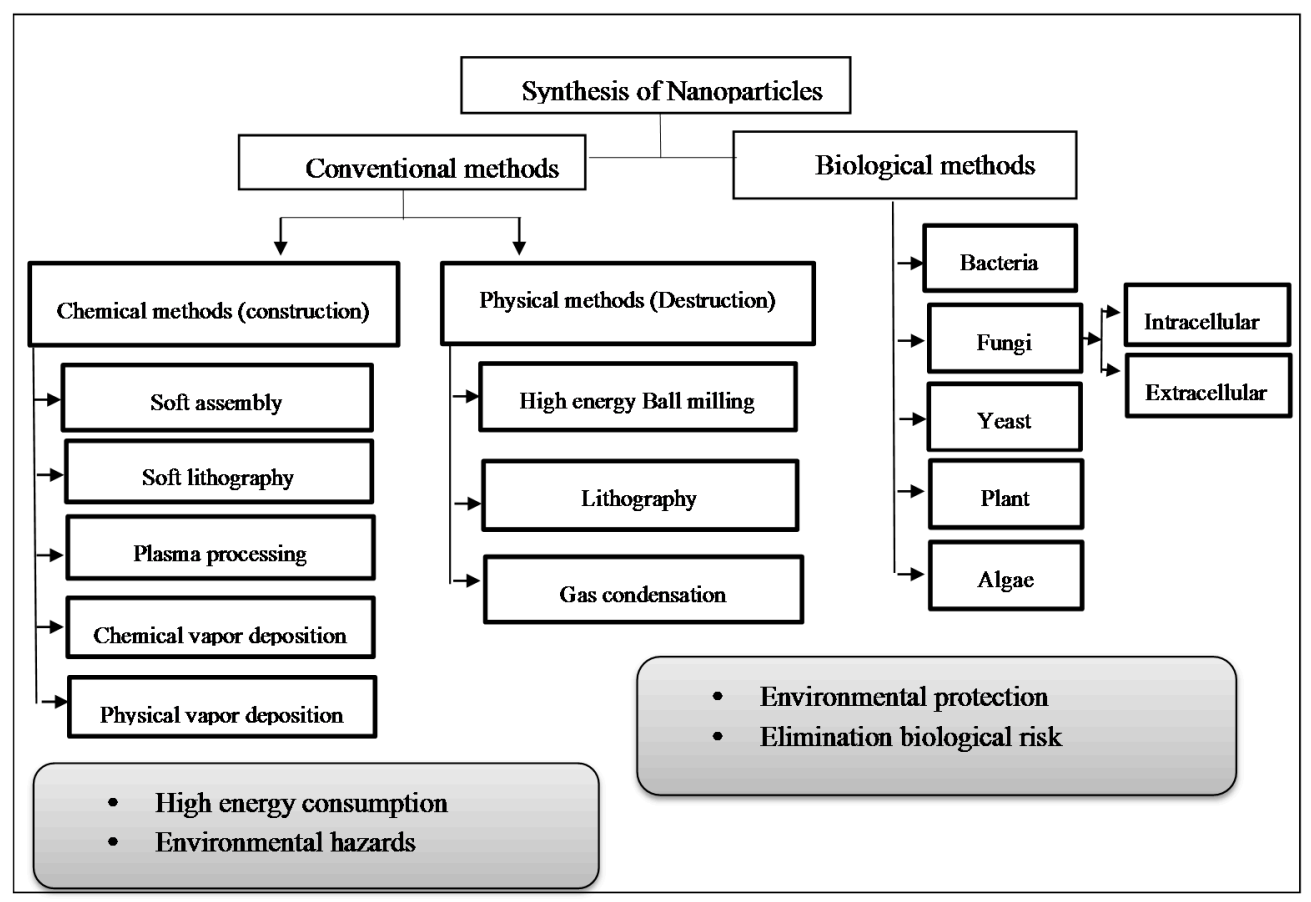

Scheme 1. Different synthetic approaches of metallic nanoparticles.

Several molecules including carbonyl groups, terpenoids, phenolic, flavones, amines, amides, proteins, pigments, alkaloids and additional decreasing factors existing in the plant extracts and microbial cells may cause synthesis of nanoparticles [13]. In this regard, the firm mechanism of metallic nanoparticles synthesis via biomass extracts is not recognized (Table 1). To produce more tiny particles in a large scale, the biosynthesis can be effectively employed [14].It is worth mentioning that NPs which are biologically synthesized reveal increased constancy [15] and they control morphology better [16].

Table 1. Possible mechanism of nanoparticle biosynthesis using different sources.

\begin{tabular}{|c|c|c|}
\hline Biomass & Possible Mechanism of Nanoparticle Biosynthesis & Reference \\
\hline $\begin{array}{l}\text { Plant } \\
>\text { Leaves } \\
>\text { Stems } \\
>\text { Roots } \\
>\text { Shoots } \\
>\text { Flowers } \\
>\text { Barks } \\
>\text { Seeds }\end{array}$ & $\begin{array}{l}\text { Secondary metabolites (alkaloids, flavonoids, saponins, steroids, tannins and } \\
\text { other nutritional compounds) acts as reducing and stabilizing agents }\end{array}$ & [17] \\
\hline $\begin{array}{l}\text { Algae } \\
>\quad \text { Macro } \\
\quad \text { algae } \\
>\quad \text { Micro } \\
\quad \text { algae } \\
\end{array}$ & $\begin{array}{l}\text { Polysaccharides have hydroxyl groups and other functionalities that can play } \\
\text { important roles in both the reduction and the stabilization of nanoparticles }\end{array}$ & [18-21] \\
\hline Fungi & $\begin{array}{l}\text { Reducing enzyme intracellularly or extracellularly and the procedure of } \\
\text { biomimetic mineralization }\end{array}$ & {$[22,23]$} \\
\hline Yeast & Membrane bound (as well as cytosolic) oxido reductases and quinones & [24] \\
\hline Bacteria & $\begin{array}{l}\text { The microbial cell reduces metal ions by use of specific reducing enzymes like } \\
\text { NADH-dependent reductase or nitrate dependent reductase }\end{array}$ & {$[25,26]$} \\
\hline
\end{tabular}




\section{Biosynthesis of Nanoparticles by Microorganisms}

It is recognized that microorganisms including bacteria, Cyanobacteria, Actinomycetes, yeast and fungi make inorganic nanoparticles such as gold, silver, calcium, silicon, iron, gypsum and lead. Because of their intrinsic potential, they produce nanoparticles, which are intra and/or extracellularly in nature [27]. However, due to extra processing phases like ultra-sonication and therapy with proper detergents, it is hard to extract the nanoparticles produced through intracellular biosynthesis [28]. As a result, screening of the microorganisms resulting in biosynthesis of nanoparticle esextracellularly is necessary [29,30]. Currently, microbial approaches in the production of nanomaterials of variable compounds are mostly restricted to metals, a few metal sulfide, and very little oxides.

All of them are confined to the microorganisms of earthy source. Culture conditions determine the biological synthesis of nanoparticles through the utilization of microorganisms and consequently, it is necessary to standardize these circumstances for the production of nanoparticles in a large scale. While strict inspection over form, size, and combination of the particles is exercised, it is recognized that many microorganisms can produce metallic nanoparticles having characteristic features similar tonanomaterial's which are synthesized chemically [31]. It is hoped that by means of hydrolytic activity of the microorganisms, other metal oxides can also be formed. In conclusion, under moderate pressures and temperatures, nano-sized materials can be produced by microorganisms. Moreover, it is inexpensive, undemanding, effective, energy-saving, and environment-friendly to make use of microbial procedure for the production of nanomaterials [32].

\section{Biosynthesis of Nanoparticles by Fungi}

Fungi are recognized as eukaryotic organisms that reside in various ordinary lodgings and they typically form decomposer organisms. From an anticipated sum of 1.5 million species of fungi on Earth only about 70,000 species have been recognized. The estimation of more recent data shows that according to high-through put sequencing methods, approximately 5.1 million fungal species are found [33]. It is worth mentioning that digesting extracellular food, discharging particular enzymes to hydrolyze complicated compositions into easier molecules, which are soaked up and utilized as an energy resource are the abilities of these organisms [33]. The exploration of the implication of fungi in nano biotechnology is considered important. In this regard, fungi have attracted more attention regarding the research on biological production of metallic nanoparticles due to their toleration and metal bioaccumulation capability [34].The easiness of fungi scale-up is a separate privilege of utilizing them in nanoparticle synthesis (e.g., utilizing a thin solid substrate fermentation technique). Since fungi are very effective secretors of extracellular enzymes, therefore achieving vast production of enzymes is feasible [35]. Economic livability and facility of employing biomass is another merit for the utilization of green approach mediated by fungal to synthesize metallic nanoparticles. Moreover, a number of species grow fast and therefore culturing and keeping them in the laboratory are very simple [36]. High wall-binding and intracellular metal uptake are the capacities of most fungi [37]. Fungi are able to produce metal nanoparticles/meso and nanostructure via reducing enzyme intracellularly or extracellularly and the procedure of biomimetic mineralization (Scheme 2) [22,23]. 


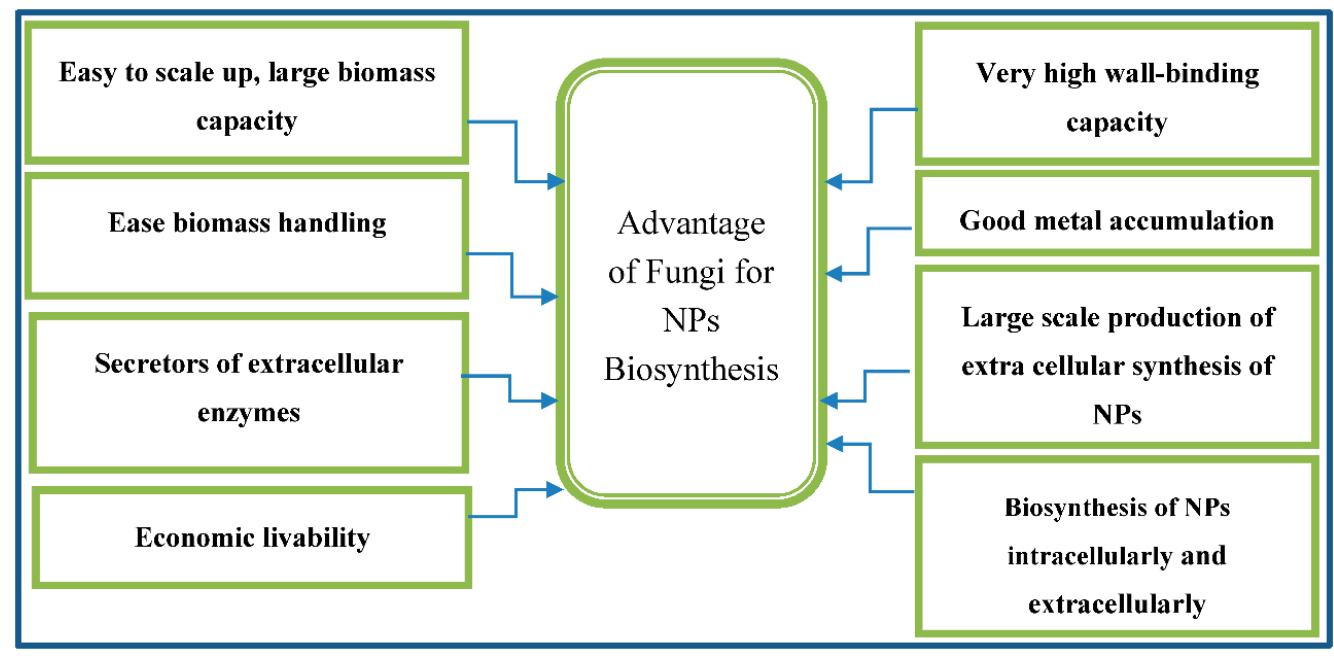

Scheme 2. Fungi have some distinct advantages when used as bio factories for NP production.

As NP processes in nanotechnology, the study of fungal species is somewhat new. One of the primary investigations of the biosynthesis of metallic NPs by means of fungi illustrates the synthesis of silver NPs extracellularly by the filamentous fungus Verticillium sp. [38]. For this aim, the filamentous fungus Fusarium oxysporum has been widely utilized species among the fungal ones identified for NP synthesis (Table 2).

In most cases, the synthesis of extracellular NPs is published, though biomass has usually exposure to metallic ion solutions [39]. First utilized fungus is reported as individual CdS NPs in addition to the formation of $\mathrm{PbS}, \mathrm{ZnS}$, and $\mathrm{MoS}_{2} \mathrm{NPs}$. A feasible sulfate diminishing enzyme-based procedure for NPs production was suggested by the existence of proteins in the aqueous solution. By utilizing the identical fungus, silver NPs were achieved which emerged separately. They can also appear through gathering with highly changing morphology in a size which ranges from of 5-50 $\mathrm{nm}$ [22].

In addition, in another study, the results showed that spherical silver NPs in a size range of 20-50 nm via the utilization of $F$. oxysporum was produced [23]; by comparison the results of the two mentioned studies [22,23], the discrepancy in morphology and size could be ascribed to variations in used temperature, although it appeared that the size of NPs did not depend on time [40]. Although the most frequently formed NPs are quasi-spherical ones, different morphologies can be achieved according to the metallic ion solution and incubation circumstances.

By employing F. oxysporum, the synthesis of NPs having different metals has been conducted [23]. Extracellular production is reported in all cases having a variety of size ranges in addition to different forms (Table 2). The decrease in the metal ions through this fungus has been related to a NADH-based reductases and a shuttle Quinone extracellular procedure [38].

In addition, it was discovered that different quantities of NADH made the synthesis of Au-Ag alloy NPs with diverse compounds possible [31]. Furthermore, purified $\alpha$-NADPH-dependent nitrate reductase producebyR. Stolonifer, as well as phytochelatin, was utilized to form silver NPs in a size range of 10-25 nm successfully [41]. In this regard, Govender et al. suggested a mechanism to reduce biologically $\mathrm{H}_{2} \mathrm{PtCl}_{6}$ and $\mathrm{PtCl}_{2}$ into platinum NPs by means of a filtered hydrogenase enzyme from $F$. oxysporum [42]. 
Table 2. Potential fungal isolates used for the biosynthesis of metal/metal oxide nanoparticles.

\begin{tabular}{|c|c|c|c|c|c|c|}
\hline Fungus Species & NPs & Localization & Size (nm) & Shape & Application & Reference \\
\hline Aspergillus fumigatus & $\mathrm{ZnO}$ & Extracellular & $1.2-6.8$ & Spherical and hexagonal & Industrial, medical and agricultural sectors & [43] \\
\hline Aspergillus oryzae & $\mathrm{FeCl}_{3}$ & - & $10-24.6$ & Spherical & Agricultural, biomedical and engineering sectors & {$[44]$} \\
\hline Aspergillus tubingensis & $\mathrm{Ca}_{3} \mathrm{P}_{2} \mathrm{O}_{8}$ & Extracellular & 28.2 & Spherical & Agricultural, biomedical and engineering sectors & [45] \\
\hline Rhizopus oryzae & $\mathrm{Au}$ & Cell surface & 10 & Nanocrystalline & Pesticides & [46] \\
\hline Rhizopus stolonifer & $\mathrm{Au}$ & - & $1-5$ & Irregularly (uniform) & - & {$[47]$} \\
\hline Aspergillus niger & $\mathrm{Au}$ & Extracellular & $10-20$ & Polydispersed & - & {$[48]$} \\
\hline Aspergillus niger & $\mathrm{Au}$ & Extracellular & $12.79 \pm 5.61$ & Spherical & - & [49] \\
\hline Aureobasidium pullulans & $\mathrm{Au}$ & Intracellular & $29 \pm 6$ & Spherical & - & {$[50]$} \\
\hline Colletotrichum $\mathrm{sp.}$ & $\mathrm{Au}$ & - & $20-40$ & Decahedral and icosahedral & - & {$[51]$} \\
\hline Fusarium semitectum & $\mathrm{Au}$ & - & 25 & Spherical & Optoelectronics & {$[52]$} \\
\hline Fusarium oxysporum & $\mathrm{Au}$ & - & $2-50$ & Spherical, monodispersity & - & {$[50]$} \\
\hline Fusarium oxysporum & $\mathrm{Au}$ & Intracellular & $128 \pm 70^{\text {a }}$ & Aggregates & - & [11] \\
\hline Helminthosporum solani & $\mathrm{Au}$ & Extracellular & $2-70$ & Polydispersed & Anti-cancer drug & [53] \\
\hline Neurospora crassa & $\mathrm{Au}$ & - & 32 & Spherical & - & [36] \\
\hline Penicillium brevicompactum & $\mathrm{Au}$ & - & $10-50$ & Spherical & To target cancer cells & {$[54]$} \\
\hline Verticillium sp. & $\mathrm{Au}$ & Cell wall & $20 \pm 8$ & Spherical & - & {$[55]$} \\
\hline Verticillium $\mathrm{sp}$. & $\mathrm{Au}$ & Cytoplsmicmembran & $20 \pm 8$ & Quasihexagonl & - & {$[55]$} \\
\hline Verticillium luteoalbum & $\mathrm{Au}$ & Intracellular & $<10$ & Spheres and rods & - & [56] \\
\hline Cylindrocladium floridanu & $\mathrm{Au}$ & Extracellular & 19.5 & Spherical & - & [57] \\
\hline Phanerochaete chrysosporium & $\mathrm{Au}$ & Extracellular & $10-100$ & Spherical & - & [58] \\
\hline Volvariella volvacea & $\mathrm{Au}$ & - & $20-150$ & Spherical & Therapeutic & {$[59]$} \\
\hline Sclerotium rolfsii & $\mathrm{Au}$ & Extracellular & 25 & Triangles, decahedral, hexagonal and rods & - & {$[60]$} \\
\hline Fusarium oxyporum & $\mathrm{Au}$ & Extracellular & $8-40$ & Spherical and triangular & - & {$[61]$} \\
\hline Fusarium oxyporum & $\mathrm{Au}$ & Extracellular & 46.21 & Spherical, triangular & - & {$[62]$} \\
\hline Colletotrichum sp. & $\mathrm{Au}$ & Extracellular & $8-40$ & Spherical & - & {$[51]$} \\
\hline Rhizopus stolonifer & $\mathrm{Au}$ & - & $1-5$ & Irregularly & - & {$[41]$} \\
\hline Verticillium luteoalbum & $\mathrm{Au}$ & Intracellular & Various & Various & - & {$[63]$} \\
\hline
\end{tabular}


Table 2. Cont.

\begin{tabular}{|c|c|c|c|c|c|c|}
\hline Fungus Species & NPs & Localization & Size (nm) & Shape & Application & Reference \\
\hline Coriolis versicolor & $\mathrm{Au}$ & $\begin{array}{l}\text { Extra- and } \\
\text { intracellular }\end{array}$ & $\begin{array}{l}20-100 \\
100-300\end{array}$ & Spherical and ellipsoidal & - & {$[64]$} \\
\hline Rhizopus oryzae & $\mathrm{Au}$ & - & Various & $\begin{array}{l}\text { Triangular, hexagonal, pentagonal, spheroidal, } \\
\text { sea urchin like, 2D nanowires, nanorods }\end{array}$ & - & [65] \\
\hline Aspergillus niger & $\mathrm{Au}$ & - & Various & Plates, aggregates, spherical & - & {$[48]$} \\
\hline Aspergillus niger & $\mathrm{Au}$ & - & Various & Nanowalls, spiral plates, spherical & - & {$[48]$} \\
\hline Aspergillus niger & $\mathrm{Au}$ & - & $50-500$ & Nanoplates & - & {$[48]$} \\
\hline Candida albicans & $\mathrm{Au}$ & - & $\begin{array}{c}20-40 \\
60-80\end{array}$ & Spherical \& nonspherical & Detection of liver cancer & [66] \\
\hline Verticillum sp. & $\mathrm{Ag}$ & Intracellular & 25 & Spherical & - & {$[38]$} \\
\hline Fusarium oxyporum & $\mathrm{Ag}$ & Extracellular & $5-15$ & Highly variable & - & {$[67]$} \\
\hline Fusarium oxyporum & $\mathrm{Ag}$ & Extracellular & $20-50$ & Spherical & Antibacterial & {$[23]$} \\
\hline Fusarium oxyporum & $\mathrm{Ag}$ & - & $10-25$ & Aggregates & - & {$[68]$} \\
\hline Aspergillus fumigatus & $\mathrm{Ag}$ & - & $5-25$ & Mostly spherical, some triangular & - & {$[69]$} \\
\hline Aspergillus niger & $\mathrm{Ag}$ & Extracellular & $3-30$ & Spherical & Antibacterial and antifungal activity & {$[70]$} \\
\hline Aspergillus fumigatus & $\mathrm{Ag}$ & - & $15-45$ & Mostly spherical & Antiviral against HIV-1 & {$[71]$} \\
\hline Pleurotus sajor caju & $\mathrm{Ag}$ & Extracellular & 30.5 & Spherical & Antibacterial activity & {$[72]$} \\
\hline Aspergillus flavus & $\mathrm{Ag}$ & On cell wall surface & 8.92 & Spherical & - & {$[73]$} \\
\hline Aspergillus niger & $\mathrm{Ag}$ & - & $5-35$ & Spherical & Antimicrobial & {$[32]$} \\
\hline Trichoderma asperellum & $\mathrm{Ag}$ & - & $13-18$ & Nanocrystalline & Agriculture & {$[74]$} \\
\hline Volvariella volvaceae & $\mathrm{Ag}$ & - & 15 & Spherical & Medical applications & {$[15]$} \\
\hline Penicillium fellutanum & $\mathrm{Ag}$ & Extracellular & $5-25$ & Mostly spherical & - & {$[75]$} \\
\hline Penicillium strain J3 & $\mathrm{Ag}$ & - & $10-100$ & Mostly spherical & - & {$[76]$} \\
\hline Cladosporium cladosporioides & $\mathrm{Ag}$ & - & $10-100$ & Mostly spherical & - & {$[77]$} \\
\hline Phoma glomerata & $\mathrm{Ag}$ & - & $60-80$ & Spherical & Antibiotic & {$[78]$} \\
\hline Coriolis versicolor & $\mathrm{Ag}$ & $\begin{array}{l}\text { Extra- and } \\
\text { intracellular }\end{array}$ & $\begin{array}{l}25-75 \\
444-491\end{array}$ & Spherical & - & {$[79]$} \\
\hline Trichoderma viride & $\mathrm{Ag}$ & - & $5-40$ & Spherical, rod-like & Antibacterial activity & {$[80]$} \\
\hline
\end{tabular}


Table 2. Cont.

\begin{tabular}{|c|c|c|c|c|c|c|}
\hline Fungus Species & NPs & Localization & Size (nm) & Shape & Application & Reference \\
\hline Trichoderma viride & $\mathrm{Ag}$ & - & $\begin{array}{l}2-4,10-40 \\
80-100\end{array}$ & Spherical & - & [81] \\
\hline Trichoderma viride & $\mathrm{Ag}$ & - & $2-4$ & Mostly spherical & $\begin{array}{l}\text { Biosensor and } \\
\text { bio imaging }\end{array}$ & {$[82]$} \\
\hline Trichoderma viride & $\mathrm{Ag}$ & Extracellular & $5-40$ & Spherical, rod-like & $\begin{array}{l}\text { synergistic effect } \\
\text { with antibiotics }\end{array}$ & {$[83]$} \\
\hline Amylomyces rouxii KSU-09 & $\mathrm{Ag}$ & - & $5-27$ & Spherical & Antimicrobial & {$[84]$} \\
\hline Aspergillus clavitus & $\mathrm{Ag}$ & Extracellular & $550-650$ & - & Antimicrobial & {$[85]$} \\
\hline Aspergillus flavus NJP08 & $\mathrm{Ag}$ & - & 17 & Spherical & - & {$[86]$} \\
\hline Rhizopus stolonifer & $\mathrm{Ag}$ & - & $25-30$ & Quasi-spherical & - & {$[41]$} \\
\hline Aspergillus terreus CZR-1 & $\mathrm{Ag}$ & Extracellular & 2.5 & Spherical & Agriculture, Biomedical and engineering sector & {$[87]$} \\
\hline Volvariella volvaceae & $\mathrm{Au}-\mathrm{Ag}$ & Extracellular & $20-150$ & Triangular & Medical application & {$[15]$} \\
\hline Fusarium oxyporum & $\mathrm{Au}-\mathrm{Ag}$ & Extracellular & $8-14$ & Quasi-spherical & - & {$[88]$} \\
\hline Fusarium oxysporum & $\mathrm{Fe}_{3} \mathrm{O}_{4}$ & Extracellular & $20-50$ & Irregular, quasi-spherical & - & [89] \\
\hline Verticillium sp. & $\mathrm{Fe}_{3} \mathrm{O}_{4}$ & Extracellular & $\begin{array}{c}100-400 \\
20-50\end{array}$ & Cubo-octahedral, quasi-spherical & - & [89] \\
\hline Aspergillus flavus & $\mathrm{TiO}_{2}$ & - & $62-74$ & Spherical & Antimicrobial & {$[90]$} \\
\hline Aspergillus flavus TFR7 & $\mathrm{TiO}_{2}$ & & $12-15$ & Extracellular & Plant nutrient & [91] \\
\hline Fusarium oxyporum & BT & Extracellular & $4-5$ & Quasi-spherical & - & {$[92]$} \\
\hline Fusarium oxyporum & $\mathrm{Cd}$ & Extracellular & $9-15$ & Spherical & - & {$[5]$} \\
\hline Fusarium oxyporum & $\mathrm{Pt}$ & - & $70-180$ & $\begin{array}{c}\text { Rectangular, triangular, spherical } \\
\text { and aggregates }\end{array}$ & - & {$[42]$} \\
\hline $\begin{array}{l}\text { Fusarium oxysporum f. sp. } \\
\text { lycopersici }\end{array}$ & $\mathrm{Pt}$ & $\begin{array}{l}\text { Extra-and } \\
\text { intracellular }\end{array}$ & $10-100$ & $\begin{array}{l}\text { Hexagonal, pentagonal, circular, } \\
\text { squares, rectangles }\end{array}$ & - & {$[40]$} \\
\hline Fusarium spp. & $\mathrm{Zn}$ & Intracellular & $100-200$ & $\begin{array}{c}\text { Irregular, } \\
\text { some spherical }\end{array}$ & - & [93] \\
\hline Aspergillus versicolor mycelia & $\mathrm{Hg}$ & Surface of mycelia & $20.5 \pm 1.82$ & Alteration & - & [94] \\
\hline Fungi isolated from the soil & $\begin{array}{l}\mathrm{Zn}, \mathrm{Mg} \\
\text { and } \mathrm{Ti}\end{array}$ & extracellular & Various & - & - & {$[95]$} \\
\hline
\end{tabular}


To synthesize metal nanoparticles successfully, a considerable amount of additional fungal species were utilized as well as F. oxysporum (Table 2). The use of fungal biomass and/or cell-free extract yielded the synthesis of metal NPs with different shapes and sizes [62].

Although different fungal species are utilized, diverse NPs are formed under the similar experimental circumstances. For example, while particles achieved from Verticillium sp. presented cubo-octahedral shapes with a size range of 100 to $400 \mathrm{~nm}$ magnetite, NPs produced by $F$. oxysporum had irregular form showing a total quasi-spherical morphology ranging in size from 20-50 nm [89]. As a result, the kind and condensation of biomolecules formed by each fungal species, different incubation circumstances, precursor resolutions used, and response time contribute to the type of NPs. By using the fungus Rhizopus oryzae in producing metallic NPs, significant results were attained. In this way, controlling the shape of gold nanoparticles at room temperature was feasible via the use of fungal extract. Therefore, NPs were produced through the manipulation of main growth factors like gold ion concentration, solution $\mathrm{pH}$, and response time $[63,65,96]$.

The possible pathogenicity to humans is the main shortcoming of the use of this organism for NP formation. The potential application of NPs formed by fungal cultures is reported by some publications; in most of these studies, the evaluation of their biological impact has been conducted.

Moreover, the results showed the victorious inhibition of microorganisms such as bacteria and fungi by the use of silver NPs alone or together with antibiotics [78]. The antimicrobial efficiency of synthesized silver NPs via the utilization of fungal species was ascertained against bacteria $[70,84]$ and fungal pathogens [84].

Other metallic NPs formed by utilizing fungi as reducing agents are less evaluated NPs; however, the nano gold-bio conjugate produced with the use of $R$. oryzae presented high antimicrobial activity against pathogenic bacteria such as P. aeruginosa, E. coli, B. subtilis, S. aureus, Salmonella sp., and the yeasts S. cerevisiae and $C$. albicans [46]. In recent years, it is proved that antimicrobial activity of fungus-interceded synthesis of $\mathrm{TiO}_{2}$ NPs can be anew antibacterial material [90].

When being faced with hydrous metal ions such as $\mathrm{AuCl}_{4}$ or $\mathrm{Ag}^{+}$, fungi like Verticillium, Fusarium oxysporum can form extracellular $[61,67]$ or intracellular $[38,55]$ metal nanoparticles. Through utilizing an entophytic fungus Colletotrichum sp. [51], Au nanoparticles of different morphologies were formed e.g., rods, flat sheets and triangles. This matter may result in characteristics of nanomaterial's which can differ from those usually showing spherical shapes. With the alteration of molar proportion of the metal ions in the synthetic solutions, alloy nanoparticles with various compounds can be achieved by means of this method. This technique can also be applied for the synthesis of additional alloy or composite systems such as Au-CdS, Ag-CdS, and CdS-PbS [88]. Moreover, fungi are able to form semiconductors in addition to metallic nanoparticles. For instance, while F. oxysporum is subjected to hydrous $\mathrm{CdSO}_{4}$ solution, it's patters sulfate-decreasing enzyme and forms extracellular CdS nanoparticles [39]. By employing the microbial procedure, metal ions (including several toxic ions) can be scuttled from ores or purification of water as well as material synthesis. Microorganisms also provide cells for size and space-constrained synthesis. Nevertheless, since not the whole minerals are produced inside the cell of microorganism and even those produced inside the cell might be influenced by the growth of the cell, so the monodispersity of the minerals may become scant. Therefore, there is a need to conduct more studies which produce higher- monodispersity nanomaterials and in a wider variety of compounds via the procedure of 
microorganism synthesis. In this article, we provide a short summary of the present study universally on the utilization of eukaryotes like yeast and fungi in the biosynthesis of nanoparticles (NPs) and their uses.

\section{Production of Nanoparticles by Using Yeast}

Due to the mass production of NPs as the easiness of controlling yeasts in laboratory circumstances, the synthesis of numerous enzymes and rapid growth with the use of simple nutrients, the yeast strains possess more benefits over bacteria [97]. Some studies have been conducted to investigate the synthesis of metallic nanoparticles employing the yeast. However, for this aim, through utilizing the eukaryotic systems, namely, Candida glabrata and S. pombe, one of the primary methods in employing biological material was attained [98].

The possible applicability of NPs formed by yeast have been shown by a few investigations. For the fabrication of a diode cadmium, intracellular synthesized sulfide NPs by $S$. pombe were applied, which had low-voltage operation and high forward current value. It is assumed that these properties can form the artificial structure a perfect diode [99].

In addition, to synthesize silver and gold NPs, yeast strains have been utilized. It was also reported that with an employment of silver tolerant yeast strain $M K Y 3$, silver nanoparticles were produced extracellularly, in which the hexagonal silver nanoparticles $(2-5 \mathrm{~nm})$ were synthesized in log stage of growth (Table 3). According to the different warming of the cases, the standardization and documentation of appropriate circumstance for the synthesis of bulky number of silver nanoparticles were also done [100].

Table 3. Nanoparticle synthesis by yeast.

\begin{tabular}{|c|c|c|c|c|c|c|}
\hline Yeast & NPs & Localization & Size (nm) & Shape & Application & Reference \\
\hline Candida glabrata & $\mathrm{CdS}$ & $\begin{array}{l}\text { Extra- and } \\
\text { intracellular }\end{array}$ & $20 \AA, 29 \AA$ & Hexamer & Physiological & {$[98]$} \\
\hline Candida glabrata & $\mathrm{CdS}$ & Intracellular & - & - & - & {$[101]$} \\
\hline Yeast strain MKY3 & $\mathrm{Ag}$ & Extracellular & $2-5$ & $\begin{array}{l}\text { Twinned or } \\
\text { multitwinned, } \\
\text { some hexagonal }\end{array}$ & - & {$[100]$} \\
\hline Schizosaccharomyces pombe & Cds & $\begin{array}{l}\text { Extra- and } \\
\text { intracellular }\end{array}$ & $18 \AA, 29 \AA$ & - & - & {$[98]$} \\
\hline Schizosaccharomyces pombe & $\mathrm{Cds}$ & Intracellular & $1-1.5$ & Hexagonal & & [99] \\
\hline Schizosaccharomyces pombe & Cds & Intracellular & - & - & & {$[101]$} \\
\hline Pichia jadinii (Candida utilis) & $\mathrm{Au}$ & Intracellular & - & Various & - & {$[63]$} \\
\hline Yarrowia lipolytica NCIM3589 & $\mathrm{Au}$ & Cell surface & Varying & Particles and plates & - & {$[102]$} \\
\hline Yeast & $\mathrm{Zr}$ & - & - & Irregular mesoporous & Fuel cells & {$[103]$} \\
\hline Yeast & $\mathrm{Zn}_{3}\left(\mathrm{PO}_{4}\right)_{2}$ & Extracellular & $\begin{array}{l}10-80 \\
80-200\end{array}$ & Rectangular & $\begin{array}{l}\text { Antirust pigment and } \\
\text { electronic luminophore }\end{array}$ & {$[104]$} \\
\hline
\end{tabular}

The incubation of Yarrowia lipolytica cells was done with changed concentrations of chloroauric acid and formed cell-related gold NPs and nano plates (Table 3). Moreover, it is found out that the quantity of cells and the utilized salt concentrations can affect the size of NPs [102]. Similarly, to fabricate an air electrode showing outstanding electro catalytic activity for oxygen decrease (ORR), zirconium phosphate with a synthesized mesoporous figuration with the use of yeast as bio template was employed [103]. So, 
as bio-based templates, the synthesis of zinc phosphate nano powders was conducted with yeasts. The synthesis of $\mathrm{Zn}_{3}\left(\mathrm{PO}_{4}\right)_{2}$ powders with butterfly similar to microstructure with a size ranging from of $10-80 \mathrm{~nm}$ in width and 80-200 $\mathrm{nm}$ in length were shown by Yan et al. [104].

\section{Biomedical Applications of Green Synthesis Nanoparticles}

Because of the high uses of metallic NPs in biomedical domains, a constant development is feasible in this area. Having numerous viewpoints to improve the diagnosis and treatment of human sicknesses, nano medicine is a growing field of study [105]. As fluorescent biological labels [105,106], gene and drug delivery factors [107,108], and in uses like bio detection of pathogens [109], tissue engineering [110,111] tumor demolition through heating (hyperthermia) [112], MRI contrast enhancement [113], phagokinetic investigations [114], and magnetic NPs seem to be suitable for targeted drug delivery and hyperthermia applications, discrete nanoparticles are commonly used in Nano biomedicine [115].

The publication of numerous reviews and articles investigating the uses of nanoparticles in biomedicine has been reported $[115,116]$. Since the domain of biosynthesized nanoparticles is somewhat novel, investigators have already began to explore their use in different areas including the delivery of drugs, cancer therapy, gene treatment and DNA analysis, antibacterial factors, biosensors, increasing response rates, separation science, and MRI. In this article, to show these applications, a number of examples are given in Scheme 3 and described below.

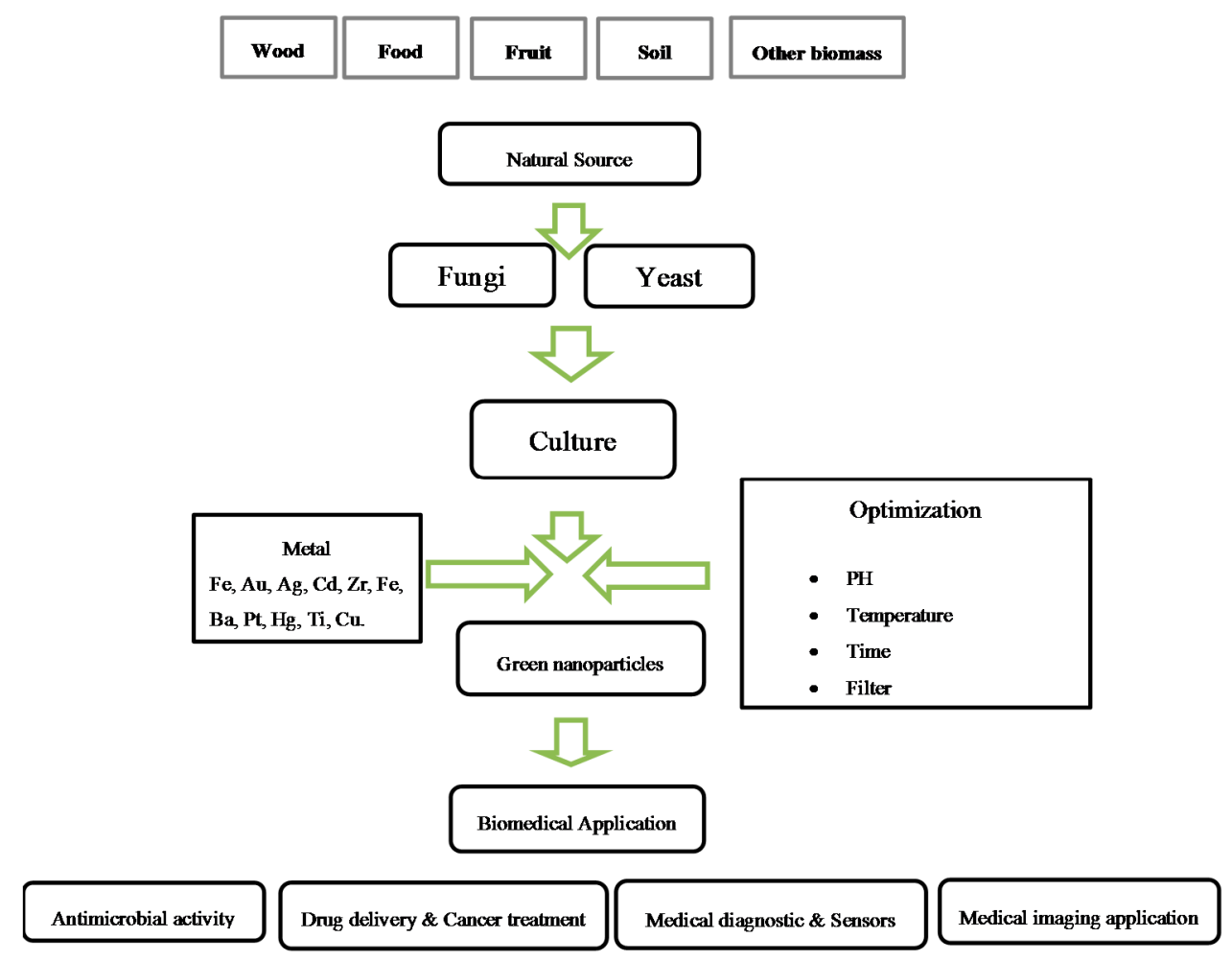

Scheme 3. Biomedical applications of metallic nanoparticles synthesis by fungi and yeast.

\subsection{Drug Delivery}

The main concern in designing and developing new drug delivery systems is the accurate and secure delivery of the drugs to their targeted places at the proper time. The reasons is achieving a controlled 
release and attaining the highest therapeutic impact. In order to reach target cells, targeted Nano conveyors must pass through blood tissue obstacles [117]. Moreover, targeted Nano carriers must have contact with cytoplasmic targets through special endocytotic and transcytotic transfer mechanisms across cellular obstacles to reach targeted cells [105].

Firstly, Ag-NPs drug conveyors are able to pass through the blood-brain hindrance and the narrow epithelial joints of the skin usually hindering the delivery of drugs to the targeted place due to their tiny size. Secondly, Nano conveyors demonstrate enhanced pharmacokinetics and bio distribution of therapeutic factors and therefore reduce poison via their privileged gathering at the targeted position owing to their elevated surface area to volume proportion [118]. It is recognized that magnetic nanoparticles such as $\mathrm{Fe}_{3} \mathrm{O}_{4}$ (magnetite) and $\mathrm{Fe}_{2} \mathrm{O}_{3}$ (maghemite) are biocompatible. They have been dynamically studied for some reasons such as target cancer therapy (magnetic hyperthermia), categorization and manipulation of stem cell, trained drug delivery, gene treatment and the examination of DNA, and MRI [119].

Gold nanoparticles have been produced as potential scaffolds for the delivery of drug and gene which have complementary role over more conventional delivery carriers [120]. Novel delivery tactics can be emerged with the amalgamation of low-innate toxicity, high-surface part, steadiness, and the role of tunability which supplies them with distinctive features. Biomedical applications of chemically synthesized Au-NPs were studied before, but to our best knowledge there are no reports on the use of biosynthesized Au-NPs for drug delivery [121]. As new therapeutic factors, silver nanoparticles have been broadly utilized which their applications have also been extended as antibacterial, antifungal, antiviral and anti-inflammatory factors. In this regard, silver nanoparticles possessing anti-angiogenic potentiality formed by Bacillus licheniformis were investigated by Kalishwaralal et al. [122].

It is predicted that the number of anticancer drugs may be considerably lessened by nanoparticle-interceded targeted delivery of drugs with better property, improved efficiency, and squat toxicities. It is believed that the rising uses of nanotechnology-based therapeutics and diagnostics in clinics will be observed in the following few years. Moreover, a further significant field which nanotechnology can have a key role in individual medicine. Any special targeted treatment may not work for each sick population because of the cancer heterogeneity and progress of drug persistence. Furthermore, magnetic nanoparticles are able to be utilized for hyperthermia cancer therapy. Hyperthermia cancer therapy refers to the administration of magnetic nanoparticles into the body, especially at cancer tissue locations. Through an external magnetic field, local heating at particular locations is possible $[112,123]$.

\subsection{Anticancer NPS}

To study biosynthesized NPs, Cytotoxicology investigations against different cancer cell lines have been reported. Some experiments utilizing synthesized Au-NPs and existing phytochemicals in grapes (Vitis vinifera) were published by Amarnath et al. [124]. These Au-NPs showed the significant similarity towards HBL-100 (human breast cancer cells), and AuNP exposure yielded HBL-100 apoptosis [124]. AuNP biosynthesis via the supernatant, live cell filtrate and biomass of the fungus Penicillium brevicompactum were investigated by Mishra et al. [54]. In another study, Jeyaraj et al. [125] evaluated Ag-NPs impacts on cancer cell lines. 


\subsubsection{Proposed Signaling Pathways of Nanoparticles Induced Apoptosis}

Cell proliferation inhibition is strictly linked with apoptosis. Apoptosis lead to induction of cell death by mitochondrial collapse, activation of caspase and following DNA fragmentation which is controlled by different molecules. Programed cell death or apoptosis consist of various signaling pathways including (1) ROS (reactive oxygen species)-dependent (2) Fas-dependent (3) p53-dependent and (4) p53 independent apoptosis. Some membranous proteins including Fas (death receptor) and FasL (Fas ligand), and increased cytoplasmic levels of proteins such as Smac/DIABLO, Bax (Bcl-2- associated X protein) and cytochrome $\mathrm{c}$ are also involved in the activation of apoptosis.

The limited literatures are available in clarifying the molecular mechanisms of nanoparticles cytotoxicity. Some studies revolve around signaling leading to cell death resulting from the cytotoxicity of these nanoparticles. For example, nanosilver induces apoptosis in $\mathrm{NIH}_{3} \mathrm{~T}_{3}$ fibroblasts via a mitochondria-mediated mechanism of release of cytochrome $\mathrm{c}$ into the cytosol and the translocation of Bax to mitochondria [126]. Similarly, Vamanu et al. noted apoptosis mechanism to be involved in the cytotoxicity of $\mathrm{TiO}_{2}$ nanoparticles in human monoblastoid cell line and shed light on the mitochondria-mediated mechanism of apoptosis [127]. Park et al. describe the mechanisms mediating oxidative stress and apoptosis induction by titanium dioxide nanoparticles in normal human bronchial epithelial cells [128]. They observed the increased ROS levels induced by treatment of those cells with titanium dioxide nanoparticles correlated with the increased caspase-3 activity, leading to cell death [128]. Zhao et al. (2009) showed that titanium dioxide $\left(\mathrm{TiO}_{2}\right)$ nanoparticles induced apoptosis in a mouse epidermal cell line (JB6 cells) in a time and dose-dependent mode. They reported remarkable mitochondrial and lysosomal membrane injury and activation of caspase- 8 , caspase-3, $\mathrm{Bid}$ and $\mathrm{Bax}$, and a decrease of $\mathrm{Bcl}-2$ by $\mathrm{TiO}_{2}$ nanoparticles [129]. The major role in $\mathrm{TiO}_{2}$-induced apoptosis is caspase-8/Bid signaling.

Although internalization of mesoporous silica nanoparticles did not affect the viability of human mesenchymal stem cell, it did induce a transient protein response and enhanced osteogenic signaling in these cells [130]. In another study $\mathrm{TiO}_{2}$ micro and nanoparticles appeared to induce apoptosis and necrosis and/or a new type of cell death mechanism that contains features of both apoptosis and necrosis in MEF cells [131]. Clearly these studies demonstrate that the mechanisms underlying the cytotoxicity of metallic nanoparticles in mammalian cell types are far from being fully understood and merit further study. Figure 1 shows proposed signaling pathways of nanoparticles induced apoptosis.

\subsubsection{Anti-Angiogenesis Signaling Pathways Possibly Modulated by Nanoparticle}

Angiogenesis, a physiological process involved in the growth of new blood vessels from pre-existing vessels, plays a key role in many diseases including diabetic retinopathy and cancer. The formation of new blood vessels is needed for the delivery of oxygen and nutrients to the tumor microenvironment [132]. Therefore, anti-angiogenic therapy is one of the most promising approaches to control tumor growth and metastasis. In normal and pathological angiogenesis, growth factors such as VEGF and fibroblast growth factor (FGF) are considered the major angiogenic factors that play a crucial role. The anti-angiogenic properties of gold nanoparticles clarify their effective role in treatment against progression of tumor models including ovarian cancer [133]. These NPs have also recently emerged as an attractive candidate for delivery of various payloads into their targets $[125,126]$. (Figure 2) shows the proposed signaling 
pathways of nanoparticles anti-angiogenesis effects. Baharara et al. demonstrated that green silver nanoparticles synthesized from Achillea bibersteinii (Ab. Ag-NPs) have cytotoxic effects on the endothelial cells. This Ab. Ag-NPs showed dose-dependent cytotoxicity against the endothelial cells. Another study also showed that Ag-NPs lead to indirect effects to the microcirculation in the chick embryo chorioallantoic membrane (CAM). These effects were associated with the partial preservation of the capillary diameters and connectivity happened without loss of embryo viability [134]. Ag-NPs could inhibit the vascular endothelial growth factor (VEGF) and effectively inhibited the formation of new blood micro vessels induced by VEGF in the mouse Matrigel plug assay [135,136]. Similar studies have confirmed the inhibitory effect of Ag-NPs on the vascular permeability induced by VEGF, interleukin (IL)-1 $\beta$, in retinal endothelial cells [136]. The mechanism may be due to induced apoptosis that affects the proteins and enzymes with thiol groups like thioredoxin, thioredoxin peroxidase and glutathione, which are responsible for neutralizing the oxidative stress of Reactive Oxygen Species (ROS) that are largely generated by mitochondrial energy metabolism [137].

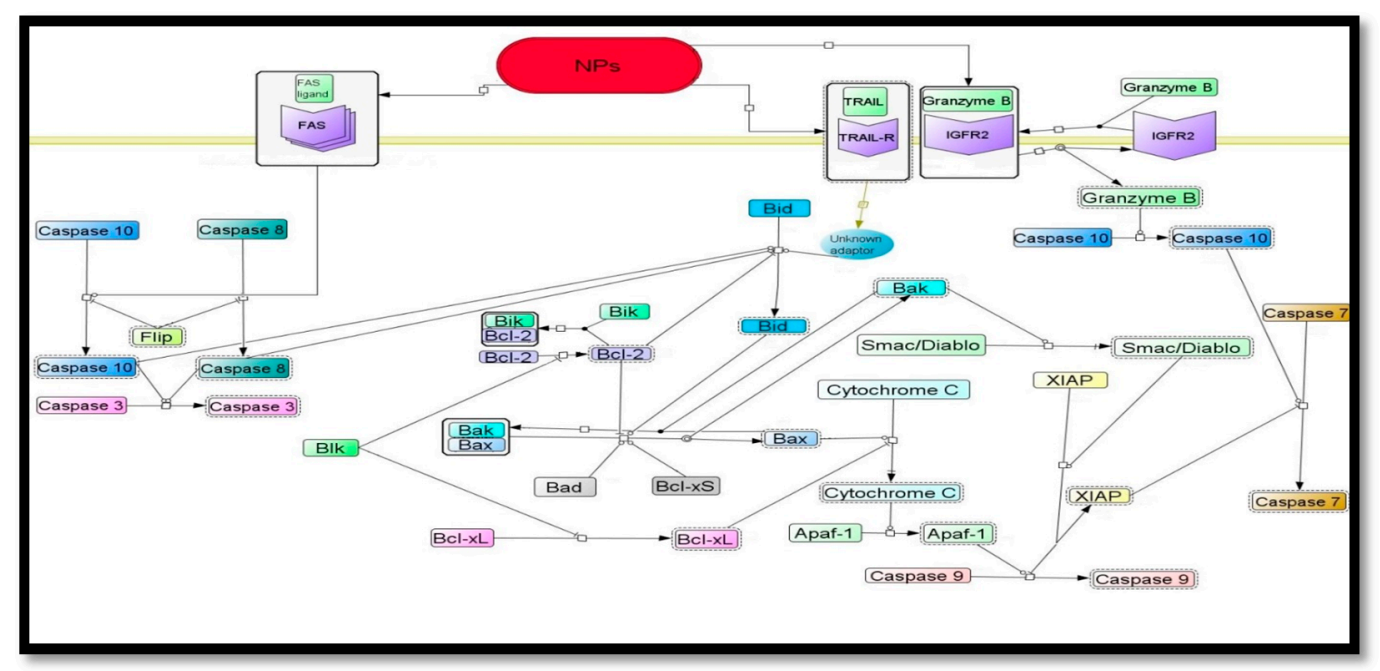

Figure 1. Proposed signaling pathways of nanoparticle induced apoptosis in cancerous cells. Apoptosis is induced by an apoptotic signal from NPs.

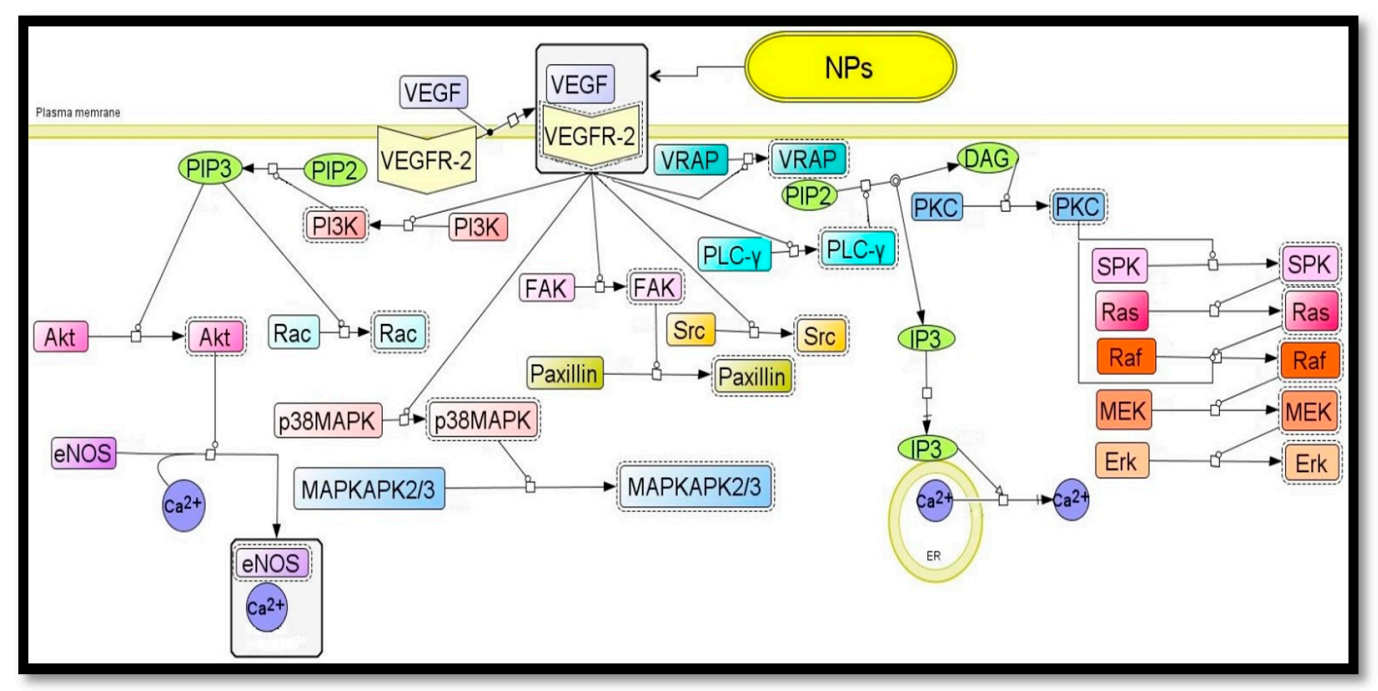

Figure 2. The proposed signaling pathways of nanoparticles anti-angiogenesis effects. 


\subsection{Antibacterial Agent}

In recent years, with the outbreak and augmentation of the resistance of microorganisms to numerous antibiotics, there has been an emphasis on silver-based antiseptics. With the utilization of fungus Trichoderma viride, the biosynthesis of silver nanoparticles was done [83]. It was found that when exposed to a filtrate of $T$. viride, aqueous silver $\left(\mathrm{Ag}^{+}\right)$ions were lessened in solution, thus resulting in the production of enormously steady Ag-NPs with the size range of 5-40 nm. In addition, the nanoparticles were investigated for their augmented antimicrobial activities with a variety of antibiotics $v s$. Gram-positive and Gram-negative bacteria. The antibacterial activities of ampicillin, kanamycin, erythromycin, and chloramphenicol were augmented with the existence of Ag-NPs vs. test strains. The maximum increasing impact was noticed for ampicillin against test strains. The findings illustrated that the amalgamation of antibiotics associated with Ag-NPs has improved antimicrobial impacts and catered for useful understanding of the formation of novel antimicrobial factors. Dur'an et al. found that to avoid or reduce the disease caused by pathogenic bacteria like Staphylococcus aureus, extracellular formed silver nanoparticles utilizing Fusarium oxysporum can be integrated into textile fabrics [138].

\section{Antifungal Activity}

Several studies have described the bacteria Aspergillus niger antifungal activity of biosynthesized NPs. Gajbhiye et al. [139] described the antifungal properties of biosynthesized NPs against Phoma glomerata, P. herbarum, Fusarium semitectum, Trichoderma sp. and Candida albicans in combination with fluconazol (a triazole antifungal drug). Ag-NPs biosynthesized by another fungus, Alternaria alternata, increased the antifungal activity of fluconazole against all tested strains except $P$. herbarum and F. semitectum. In another study, to biosynthesize the Ag-NPs efficient against the bacteria Shigella dysenteriae type I, Staphylococcus aureus, Citrobacter sp., E. coli, Pseudomonas aeruginosa and Bacillus subtilis, as well as the fungi Candida albicans and Fusarium oxysporum, mycelia-free water extracts of the fungal strain Amylomyces rouxii were utilized [84]. Moreover, the antifungal activity of biosynthesized Au-NPs has been described. Das et al. [46] synthesized the Au-NPs on the fungus surface, Rhizopusoryzae and they showed the growth inhibition of $\mathrm{G}^{-}$and $\mathrm{G}^{+}$bacterial strains, in addition to the fungi Saccharomyces cerevisiae and C. albicans. Au-NPs preventing the development of C. albicans have also been achieved following the biosynthesis with the use of a banana peel extract [140].

\subsection{Biosensor}

Nanoparticles have appealing optical and electronic features and can be utilized in biosensor applications. Zheng et al. found that the yeast cells-mediated biosynthesis of Au-Ag alloy nanoparticles were used for the fabrication of a susceptible electronically chemical vanillin sensor [141]. In addition, electrochemical-based studies showed that the vanillin sensor based on Au-Ag alloy nanoparticles-modified glassy carbon electrode has the ability to increase the electro chemical response of vanillin for the minimum of five times. The oxidation climax flow of vanillin at the sensor augmented in a linear way with its condensation in the size range of $0.2-50 \mu \mathrm{M}$ with small detection limit of $40 \mathrm{nM}$ under favorable functioning circumstances. To determine the vanillin among vanilla bean and the sample of vanilla tea, this vanillin sensor was used. It is suggestive that it may be usefully applied in vanillin controlling 
systems. In a different investigation, according to observations showing the augmentation of the enzyme activity of GOx by Au-NPs, AuNP-based- glucose oxidase (GOx) biosensors were formed [142]. The range of linear response for the glucose biosensor is $20 \mu \mathrm{M}$ to $0.80 \mathrm{mM}$ glucose with a detection limit of $17 \mu \mathrm{M}(\mathrm{S} / \mathrm{N}=3)$. To find the glucose content in business glucose injections, this kind of biosensor was used.

\subsection{Medical Imaging}

There has been an interest in the exploration of the optical features of metallic nano crystals recently. The formation of metal NPs with different sizes, forms and dielectric features has been feasible via the integration of biosynthesis techniques. Optical characteristics connected with metallic NPs involve a low or high-refractive indicator, great clearness, new photoluminescence features photonic crystals and Plasmon resonance [143]. Moreover, Nano photonics is a domain, where the light interacts with particles more tiny than its wave-length resulting in novel phenomena, like localized surface Plasmon resonance and a size-reliant semiconductor band gap [144]. By making use of a Trichoderma viride filtrate, fungal-mediated Ag-NPs were formed. After laser excitation, photoluminescence measurements emissioned in the range of 320-520 nm, allowing such Ag-NPs suitable for upcoming uses of labeling and imaging. Sarkar et al. also conducted an identical investigation [145]. The vast contact of susceptible tissues out of the operational domain has been regarded as a significant difficulty of modern laser medicine. Therefore, by locating dyes allowing the turnable blurring of the radiation onto the surface of irradiated tissues, this difficulty can be resolved. This phenomenon is named as optical radiation limiting [146]. Two more studies investigating the cadmium telluride quantum dots (CdTe QDs) fabricated through extracellular synthesis with the use of Saccharomyces cerevisiae [147] and Escherichia coli were published by other researchers [148]. These researchers examined the NP's size-based optical features. The results showed that CdTe QD were rather tiny, covered with protein and had high solvable ability in water. By employing UV-visible spectroscopy and spectrofluorimetry with photoluminescence emission from 488 to $551 \mathrm{~nm}$, the optical features were investigated in both samples. CdTe QDs associated with folic acid were utilized in vitro imaging of cancer cells, and were identified to have biocompatibility in a cytotoxicity assay [148].

\section{Conclusions}

The "green" method for nanoparticle synthesis, which is rapidly replacing traditional chemical syntheses, is of great interest because of eco-friendliness, economic views, feasibility and wide range of applications in several areas such as nano medicine and catalysis medicine. Recently, various types of biological units which serve a dual role as both the reducing and stabilizing agents have been used in the synthesis of bioactive nanoparticles. As summarized in this review, biologically active products from fungi and yeast represent excellent scaffolds for this purpose. Since the domain of biosynthesized nanoparticles is somewhat novel, in this article their use in different areas including the delivery of drug, cancer therapy, gene treatment and DNA analysis, antibacterial factors, biosensors, increasing response rates, separation science, and MRI are provided. 


\section{Acknowledgments}

The authors are grateful to the UPM (Universiti Putra Malaysia) for their assistance.

\section{Author Contributions}

Farideh Namvar designed and supervised the review process, analyzed the data and search results and wrote and edited the paper; Amin Boroumand Moghaddam, Mona Moniri and Susan Azizi search, analyzed the data and wrote the paper; Rosfarizan Mohamad and Parida Md. Tahir designed, analyzed data and wrote and edited the paper.

\section{Conflicts of Interest}

The authors declare no conflict of interest.

\section{References}

1. Mohanpuria, P.; Rana, N.K.; Yadav, S.K. Biosynthesis of nanoparticles: Technological concepts and future applications. J. Nanopart. Res. 2008, 10, 507-517.

2. Liu, J.; Qiao, S.Z.; Hu, Q.H. Magnetic nanocomposites with mesoporous structures: Synthesis and applications. Small 2011, 7, 425-443.

3. Jain, K.K. Applications of nanobiotechnology in clinical diagnostics. Clin. Chem. 2007, 53, 2002-2009.

4. Kim, Y.C.; Park, N.C.; Shin, J.S.; Lee, S.R.; Lee, Y.J.; Moon, D.J. Partial oxidation of ethylene to ethylene oxide over nanosized $\mathrm{Ag} / \alpha-\mathrm{Al}_{2} \mathrm{O}_{3}$ catalysts. Catal. Today 2003, 87, 153-162.

5. Kumar, S.A.; Ansary, A.A.; Ahmad, A.; Khan, M.I. Extracellular biosynthesis of CdSe quantum dots by the fungus, Fusarium oxysporum. J. Biomed. Nanotechnol. 2007, 3, 190-194.

6. Anker, J.N.; Hall, W.P.; Lyandres, O.; Shah, N.C.; Zhao, J.; van Duyne, R.P. Biosensing with plasmonic nanosensors. Nat. Mater. 2008, 7, 442-453.

7. Pinna, N.; Niederberger, M. Oxide Synthesis as Cornerstone of Nanoscience. Eur. J. Inorg. Chem. 2008, 2008, 825, doi:10.1002/ejic.200890010.

8. Voldman, J.; Gray, M.L.; Schmidt, M.A. Microfabrication in biology and medicine. Annu. Rev. Biomed. Eng. 1999, 1, 401-425.

9. Chen, Y.; Pépin, A. Nanofabrication: Conventional and nonconventional methods. Electrophoresis 2001, 22, 187-207.

10. Piner, R.D.; Zhu, J.; Xu, F.; Hong, S. “Dip-Pen” Nanolithography. Science 1999, 283, 661-664.

11. Mandal, D.; Bolander, M.E.; Mukhopadhyay, D.; Sarkar, G.; Mukherjee, P. The use of microorganisms for the formation of metal nanoparticles and their application. Appl. Microbiol. Biotechnol. 2006, $69,485-492$.

12. Sotiropoulou, S.; Sierra-Sastre, Y.; Mark, S.S.; Batt, C.A. Biotemplated Nanostructured Materials. Chem. Mater. 2008, 20, 821-834.

13. Klaus, T.; Joerger, R.; Olsson, E.; Granqvist, C.G. Silver-based crystalline nanoparticles, microbially fabricated. Proc. Natl. Acad. Sci. USA 1999, 96, 13611-13614. 
14. Nagajyothi, P.C.; Lee, K.D. Synthesis of Plant-Mediated Silver Nanoparticles Using Dioscorea batatas Rhizome Extract and Evaluation of Their Antimicrobial Activities. J. Nanomater. 2011, $2011,1-7$.

15. Thakkar, K.N.; Mhatre, S.S.; Parikh, R.Y. Biological synthesis of metallic nanoparticles. Nanomedicine 2010, 6, 257-262.

16. Sriram, M.I.; Kalishwaralal, K.; Gurunathan, S. Biosynthesis of silver and gold nanoparticles using Bacillus licheniformis. Methods Mol. Biol. 2012, 906, 33-43.

17. Kuppusamy, P.; Yousoff, M.M.; Manian, G.P.; Govindan, N. Biosynthesis of metallic nanoparticles using plant derivatives and their new avenues in pharmacological applications - An updated report. Saudi Pharm. J. 2014, doi:10.1016/j.jsps.2014.11.013.

18. Ghodake, G.; Lee, D.S. Biological synthesis of gold nanoparticlesa using the aqueous extract of the brown algae Laminaria japonica. J. Nanoelectron. Optoelectron. 2011, 6, 268-271.

19. Azizi, S.; Ahmad, M.B.; Namvar, F.; Mohamad, R. Green biosynthesis and characterization of zinc oxide nanoparticles using brown marine macroalga Sargassum muticum aqueous extract. Mater. Lett. 2014, 116, 275-277.

20. Mahdavi, M.; Namvar, F.; Ahmad, M.B.; Mohammad, R. Green biosynthesis and characterization of magnetic iron oxide $\left(\mathrm{Fe}_{3} \mathrm{O}_{4}\right)$ nanoaprticles using seaweed (Sargassum muticum) aqueous extract. Molecules 2013, 18, 5954-5964.

21. Azizi, S.; Namvar, F.; Mahdavi, M.; Ahmad, M.B.; Mohamad, R. Biosynthesis of silver nanoparticles using brown marine macroalga, Sargussum muticum aqueous extract. Materials 2013, 6, 5942-5950.

22. Ahmad, A.; Senapati, S.; Khan, M.I.; Kumar, R.; Ramani, R.; Srinivas, V.; Sastry, M. Intracellular synthesis of gold nanoparticles by a novel alkalotolerant actinomycete, Rhodococcus species. Nanotechnology 2003, 14, 824-828.

23. Durán, N.; Marcato, P.D.; Alves, O.L.; de Souza, G.I.H.; Esposito, E. Mechanistic aspects of biosynthesis of silver nanoparticles by several Fusarium oxysporum strains. J. Nanobiotechnol. 2005, 3, doi:10.1186/1477-3155-3-8.

24. Botham, K.M.; Mayes, P.A. Biologic Oxidation. In Harper's Illustrared Biochemistry, 28th ed.; Lange-McGraw Hill: London, UK, 2006; p. 47.

25. Durán, N.; Marcato, P.D.; Durán, M., Yadav, A.; Gade, A.; Rai, M. Mechanistic aspects in the biogenic synthesis of extracellular metal nanoparticles by peptides, bacteria, fungi, and plants. Appl. Microbiol. Biotechnol. 2011, 90, 1609-1624.

26. Mishra, S.; Dixit, S.; Soni, S. Methods of nanoparticles biosynthesis for medical and commercial applications. Bio-Nanopart. Biosynth. Sustain. Biotechnol. Implic. 2015, 141-154, doi:10.1002/9781118677629.ch7.

27. Asmathunisha, N.; Kathiresan, K. A review on biosynthesis of nanoparticles by marine organisms. Colloids Surf. B Biointerfaces 2013, 103, 283-287.

28. Sharma, N.C.; Sahi, S.V.; Nath, S.; Parsons, J.G.; Gardea-Torresdey, J.L.; Pal, T. Synthesis of plant-mediated gold nanoparticles and catalytic role of biomatrix embedded nanomaterials. Environ. Sci. Technol. 2007, 41, 5137-5142.

29. Vigneshwaran, N.; Kathe, A.A.; Varadarajan, P.V; Nachane, R.P.; Balasubramanya, R.H. Biomimetics of silver nanoparticles by white rot fungus, Phaenerochaete chrysosporium. Colloids Surf. B. Biointerfaces 2006, 53, 55-59. 
30. Huang, X.; Neretina, S.; El-Sayed, M.A. Gold nanorods: From synthesis and properties to biological and biomedical applications. Adv. Mater. 2009, 21, 4880-4910.

31. MubarakAli, D.; Gopinath, V.; Rameshbabu, N.; Thajuddin, N. Synthesis and characterization of CdS nanoparticles using C-phycoerythrin from the marine cyanobacteria. Mater. Lett. 2012, 74, 8-11.

32. Kathiresan, K.; Alikunhi, N.M.; Pathmanaban, S.; Nabikhan, A.; Kandasamy, S. Analysis of antimicrobial silver nanoparticles synthesized by coastal strains of Escherichia coli and Aspergillus niger. Can. J. Microbiol. 2010, 56, 1050-1059.

33. Blackwell, M. The fungi: 1, 2, 3 ... 5.1 million species? Am. J. Bot. 2011, 98, 426-438.

34. Sastry, M.; Ahmad, A.; Islam Khan, M.; Kumar, R. Biosynthesis of metal nanoparticles using fungi and actinomycete. Curr. Sci. 2003, 85, 162-170.

35. Castro-Longoria, E.; Moreno-Velásquez, S.D.; Vilchis-Nestor, A.R.; Arenas-Berumen, E.; Avalos-Borja, M. Production of Platinum Nanoparticles and Nanoaggregates Using Neurospora crassa. J. Microbiol. Biotechnol. 2012, 22, 1000-1004.

36. Castro-Longoria, E.; Vilchis-Nestor, A.R.; Avalos-Borja, M. Biosynthesis of silver, gold and bimetallic nanoparticles using the filamentous fungus Neurospora crassa. Colloids Surf. B Biointerfaces 2011, 83, 42-48.

37. Volesky, B.; Holan, Z.R. Biosorption of heavy metals. Biotechnol. Prog. 1995, 11, 235-250.

38. Mukherjee, P.; Ahmad, A.; Mandal, D.; Senapati, S.; Sainkar, S.R.; Khan, M.I.; Parishcha, R.; Ajaykumar, P.V.; Alam, M.; Kumar, R.; et al. Fungus-Mediated Synthesis of Silver Nanoparticles and Their Immobilization in the Mycelial Matrix: A Novel Biological Approach to Nanoparticle Synthesis. Nano Lett. 2001, 1, 515-519.

39. Ahmad, A.; Mukherjee, P.; Mandal, D.; Senapati, S.; Khan, M.I.; Kumar, R.; Sastry, M. Enzyme mediated extracellular synthesis of CdS nanoparticles by the fungus, Fusarium oxysporum. J. Am. Chem. Soc. 2002, 124, 12108-12109.

40. Riddin, T.L.; Gericke, M.; Whiteley, C.G. Analysis of the inter- and extracellular formation of platinum nanoparticles by Fusarium oxysporum $\mathrm{f}$. sp. lycopersici using response surface methodology. Nanotechnology 2006, 17, 3482-3489.

41. Binupriya, A.R.; Sathishkumar, M.; Yun, S.I. Biocrystallization of silver and gold ions by inactive cell filtrate of Rhizopus stolonifer. Colloids Surf. B. Biointerfaces 2010, 79, 531-534.

42. Govender, Y.; Riddin, T.; Gericke, M.; Whiteley, C.G. Bioreduction of platinum salts into nanoparticles: A mechanistic perspective. Biotechnol. Lett. 2009, 31, 95-100.

43. Raliya, R.; Tarafdar, J.C. ZnO nanoparticle biosynthesis and its effect on phosphorous-mobilizing enzyme secretion and gum contents in Clusterbean (Cyamopsis tetragonoloba L.). Agirc. Res. 2013, 2, 48-57.

44. Raliya, R. Rapid, low-cost, and ecofriendly approach her for iron nanoparticle synthesis using Aspergillus oryzae TFR9. J. Nanoparticles 2013, 2013, doi:10.1155/2013/141274.

45. Tarafdar, J.C.; Raliya, R.; Rathore, I. Microbial synthesis of phosphorous nanoparticle from tri-calcium phosphate using Aspergillus tubingensis TFR-5. J. Bionanosci. 2012, 6, 84-89.

46. Das, S.K.; Das, A.R.; Guha, A.K. Gold Nanoparticles: Microbial Synthesis and Application in Water Hygiene Management. Langmuir 2009, 25, 8192-8199.

47. Sarkar, J.; Ray, S.; Chattopadhyay, D.; Laskar, A.; Acharya, K. Mycogenesis of gold nanoparticles using a phytopathogen Alternaria alternata. Bioprocess Biosyst. Eng. 2012, 35, 637-643. 
48. Xie, J.; Lee, J.Y.; Wang, D.I.C.; Ting, Y.P. High-yield synthesis of complex gold nanostructures in a fungal system. J. Phys. Chem. C 2007, 111, 16858-16865.

49. Bhambure, R.; Bule, M.; Shaligram, N.; Kamat, M.; Singhal, R. Extracellular biosynthesis of gold nanoparticles using Aspergillus niger-Its characterization and stability. Chem. Eng. Technol. 2009, 32, 1036-1041.

50. Zhang, X.; He, X.; Wang, K.; Yang, X. Different active biomolecules involved in biosynthesis of gold nanoparticles by three fungus species. J. Biomed. Nanotechnol. 2011, 7, 245-254.

51. Shankar, S.S.; Ahmad, A.; Pasricha, R.; Sastry, M. Bioreduction of chloroaurate ions by geranium leaves and its endophytic fungus yields gold nanoparticles of different shapes. J. Mater. Chem. 2003, 13, 1822-1826.

52. Sawle, B.D.; Salimath, B.; Deshpande, R.; Bedre, M.D.; Prabhakar, B.K.; Venkataraman, A. Biosynthesis and stabilization of $\mathrm{Au}$ and $\mathrm{Au}-\mathrm{Ag}$ alloy nanoparticles by fungus, Fusarium semitectum. Sci. Technol. Adv. Mater. 2008, 9, doi:10.1088/1468-6996/9/3/035012.

53. Kumar, S.A.; Peter, Y.A.; Nadeau, J.L. Facile biosynthesis, separation and conjugation of gold nanoparticles to doxorubicin. Nanotechnology 2008, 19, doi:10.1088/0957-4484/19/49/495101.

54. Mishra, A.; Tripathy, S.; Wahab, R.; Jeong, S.H.; Hwang, I.; Yang, Y.B.; Kim, Y.S.; Shin, H.S.; Yun, S.I. Microbial synthesis of gold nanoparticles using the fungus Penicillium brevicompactum and their cytotoxic effects against mouse mayo blast cancer $\mathrm{C} 2 \mathrm{C} 12$ cells. Appl. Microbiol. Biotechnol. 2011, 92, 617-630.

55. Mukherjee, P.; Ahmad, A.; Mandal, D.; Senapati, S.; Sainkar, S.R.; Khan, M.I.; Ramani, R.; Parischa, R.; Ajayakumar, P. V; Alam, M. Bioreduction of $\mathrm{AuCl}_{4}^{-}$ions by the fungus, Verticillium sp. and surface trapping of the gold nanoparticles formed. Angew. Chem. Int. Ed. 2001, 40, 3585-3588.

56. Gericke, M.; Pinches, A. Microbial Production of Gold Nanoparticles. Gold Bull. 2006, 39, 22-28.

57. Narayanan, K.; Sakthivel, N. Mycocrystallization of gold ions by the fungus Cylindrocladium floridanum. World J. Microbiol. Biotechnol. 2013, 29, 2207-2211.

58. Sanghi, R.; Verma, P.; Pouri, S. Enzymatic Formation of Gold Nanoparticles Using Phanerochaete chrysosporium. Sci. Res. 2011, 1, 154-162.

59. Philip, D. Biosynthesis of $\mathrm{Au}, \mathrm{Ag}$ and $\mathrm{Au}-\mathrm{Ag}$ nanoparticles using edible mushroom extract. Spectrochim. Acta Part A Mol. Biomol. Spectrosc. 2009, 73, 374-381.

60. Narayanan, K.B.; Sakthivel, N. Facile green synthesis of gold nanostructures by NADPH-dependent enzyme from the extract of Sclerotium rolfsii. Colloids Surf. A Physicochem. Eng. Asp. 2011, 380, $156-161$.

61. Mukherjee, P.; Senapati, S.; Mandal, D.; Ahmad, A.; Khan, M.I.; Kumar, R.; Sastry, M. Extracellular synthesis of gold nanoparticles by the fungus Fusarium oxysporum. ChemBioChem 2002, 3, 461-463.

62. Shankar, S.S.; Ahmad, A.; Pasricha, R.; Khan, M.I.; Kumar, R.; Sastry, M. Immobilization of biogenic gold nanoparticles in thermally evaporated fatty acid and amine thin films. J. Colloid Interface Sci. 2004, 274, 69-75.

63. Gericke, M.; Pinches, A. Biological synthesis of metal nanoparticles. Hydrometallurgy 2006, 83, 132-140.

64. Sanghi, R.; Verma, P. pH dependant fungal proteins in the "green" synthesis of gold nanoparticles. Adv. Mater. Lett. 2010, 1, 193-199. 
65. Das, S.K.; Das, A.R.; Guha, A.K. Microbial synthesis of multishaped gold nanostructures. Small 2010, 6, 1012-1021.

66. Chuhan, A.; Zubair, S.; Tufail, S.; Sherwani, A.; Sajid, M.; Raman, S.C.; Azam, A.; Owais, M. Fungus-mediated biological synthesis of gold nanoparticles : Potential in detection of liver cancer. Int. J. Nanomed. 2011, 6, 2305-2319.

67. Ahmad, A.; Mukherjee, P.; Senapati, S.; Mandal, D.; Khan, M.I.; Kumar, R.; Sastry, M. Extracellular biosynthesis of silver nanoparticles using the fungus Fusarium oxysporum. Colloids Surf. B Biointerfaces 2003, 28, 313-318.

68. Kumar, S.A.; Abyaneh, M.K.; Gosavi, S.W.; Kulkarni, S.K.; Pasricha, R.; Ahmad, A.; Khan, M.I. Nitrate reductase-mediated synthesis of silver nanoparticles from $\mathrm{AgNO}_{3}$. Biotechnol. Lett. 2007, 29, 439-445.

69. Bhainsa, K.C.; D’Souza, S.F. Extracellular biosynthesis of silver nanoparticles using the fungus Aspergillus fumigatus. Colloids Surf. B Biointerfaces 2006, 47, 160-164.

70. Jaidev, L.R.; Narasimha, G. Fungal mediated biosynthesis of silver nanoparticles, characterization and antimicrobial activity. Colloids Surf. B Biointerfaces 2010, 81, 430-433.

71. Alani, F.; Moo-Young, M.; Anderson, W. Biosynthesis of silver nanoparticles by a new strain of Streptomyces sp. compared with Aspergillus fumigatus. World J. Microbiol. Biotechnol. 2012, 28, 1081-1086.

72. Vigneshwaran, N.; Kathe, A. Silver-protein (core-shell) nanoparticle production using spent mushroom substrate. Langmuir 2007, 23, 7113-7117.

73. Vigneshwaran, N.; Ashtaputre, N.M.; Varadarajan, P.V.; Nachane, R.P.; Paralikar, K.M.; Balasubramanya, R.H. Biological synthesis of silver nanoparticles using the fungus Aspergillus flavus. Mater. Lett. 2007, 61, 1413-1418.

74. Mukherjee, P.; Roy, M.; Mandal, B.P.; Dey, G.K.; Mukherjee, P.K.; Ghatak, J.; Tyagi, A.K.; Kale, S.P. Green synthesis of highly stabilized nanocrystalline silver particles by a non-pathogenic and agriculturally important fungus $T$. asperellum. Nanotechnology. 2008, 19, 1-7.

75. Kathiresan, K.; Manivannan, S.; Nabeel, M.; Dhivya, B. Studies on silver nanoparticles synthesized by a marine fungus, Penicillium fellutanum isolated from coastal mangrove sediment. Colloids Surf. B Biointerfaces 2009, 71, 133-137.

76. Maliszewska, I.; Szewczyk, K.; Waszak, K. Biological synthesis of silver nanoparticles. J. Phys. Conf. Ser. 2009, 146, doi:10.1088/1742-6596/146/1/012025.

77. Balaji, D.S.; Basavaraja, S.; Deshpande, R.; Mahesh, D.B.; Prabhakar, B.K.; Venkataraman, A. Extracellular biosynthesis of functionalized silver nanoparticles by strains of Cladosporium cladosporioides fungus. Colloids Surf. B Biointerfaces 2009, 68, 88-92.

78. Birla, S.S.; Tiwari, V.V.; Gade, A.K.; Ingle, A.P.; Yadav, A.P.; Rai, M.K. Fabrication of silver nanoparticles by Phoma glomerata and its combined effect against Escherichia coli, Pseudomonas aeruginosa and Staphylococcus aureus. Lett. Appl. Microbiol. 2009, 48, 173-179.

79. Sanghi, R.; Verma, P. Biomimetic synthesis and characterisation of protein capped silver nanoparticles. Bioresour. Technol. 2009, 100, 501-504.

80. Fayaz, A.M.; Balaji, K.; Girilal, M.; Kalaichelvan, P.T.; Venkatesan, R. Mycobased synthesis of silver nanoparticles and their incorporation into sodium alginate films for vegetable and fruit preservation. J. Agric. Food Chem. 2009, 57, 6246-6252. 
81. Fayaz, A.M.; Balaji, K.; Kalaichelvan, P.T.; Venkatesan, R. Fungal based synthesis of silver nanoparticles - An effect of temperature on the size of particles. Colloids Surf. B Biointerfaces 2009, 74, 123-126.

82. Fayaz, M.; Tiwary, C.S.; Kalaichelvan, P.T.; Venkatesan, R. Blue orange light emission from biogenic synthesized silver nanoparticles using Trichoderma viride. Colloids Surf. B Biointerfaces 2010, 75, 175-178.

83. Fayaz, A.M.; Balaji, K.; Girilal, M.; Yadav, R.; Kalaichelvan, P.T.; Venketesan, R. Biogenic synthesis of silver nanoparticles and their synergistic effect with antibiotics: A study against gram-positive and gram-negative bacteria. Nanomed. Nanotechnol. Biol. Med. 2010, 6, 103-109.

84. Musarrat, J.; Dwivedi, S.; Singh, B.R.; Al-Khedhairy, A.A.; Azam, A.; Naqvi, A. Production of antimicrobial silver nanoparticles in water extracts of the fungus Amylomyces rouxii strain KSU-09. Bioresour. Technol. 2010, 101, 8772-8776.

85. Saravanan, M.; Nanda, A. Extracellular synthesis of silver bionanoparticles from Aspergillus clavatus and its antimicrobial activity against MRSA and MRSE. Colloids Surf. B Biointerfaces 2010, 77, 214-218.

86. Jain, N.; Bhargava, A.; Majumdar, S.; Tarafdar, J.C.; Panwar, J. Extracellular biosynthesis and characterization of silver nanoparticles using Aspergillus flavus NJP08: A mechanism perspective. Nanoscale 2011, 3, 635-641.

87. Raliya, R.; Tarafdar, J.C. Novel approach for silver nanoparticle synthesis using Aspergillus terreus CZR-1: mechanism perspective. J. Bionanosci. 2012, 6, 12-16.

88. Senapati, S.; Ahmad, A.; Khan, M.I.; Sastry, M.; Kumar, R. Extracellular biosynthesis of bimetallic Au-Ag alloy nanoparticles. Small 2005, 1, 517-520.

89. Bharde, A.; Rautaray, D.; Bansal, V.; Ahmad, A.; Sarkar, I.; Yusuf, S.M.; Sanyal, M.; Sastry, M. Extracellular biosynthesis of magnetite using fungi. Small 2006, 2, 135-141.

90. Rajakumar, G.; Rahuman, A.; Roopan, S.M.; Khanna, V.G.; Elango, G.; Kamaraj, C.; Zahir, A.A.; Velayutham, K. Fungus-mediated biosynthesis and characterization of $\mathrm{TiO}_{2}$ nanoparticles and their activity against pathogenic bacteria. Spectrochim. Acta A Mol. Biomol. Spectrosc. 2012, 91, 23-29.

91. Raliya, R.; Biswas, P.; Tarafdar, J.C. $\mathrm{TiO}_{2}$ nanoparticle biosynthesis and its physiological effect on mung bean (Vigna radiata L.). Biotechnol. Rep. 2015, 5, 22-26.

92. Bansal, V.; Poddar, P.; Ahmad, A.; Sastry, M. Room-Temperature Biosynthesis of Ferroelectric Barium Titanate Nanoparticles. J. Am. Chem. Soc. 2006, 128, 11958-11963.

93. Velmurugan, P.; Shim, J.; You, Y.; Choi, S.; Kamala-Kannan, S.; Lee, K.J.; Kim, H.J.; Oh, B.T. Removal of zinc by live, dead, and dried biomass of Fusarium spp. isolated from the abandoned-metal mine in South Korea and its perspective of producing nanocrystals. J. Hazard. Mater. 2010, 182, 317-324.

94. Das, S.; Das, A.; Guha, A. Adsorption behavior of mercury on functionalized Aspergillus versicolor mycelia: Atomic force microscopic study. Langmuir 2008, 25, 360-366.

95. Raliya, R.; Rathore, I.; Tarafdar, J.C. Developmental of microbial nanofactory for zinc, magnesium and titanium nanoparticles production using soil fungi. J. Bionanosci. 2013, 7, 59-96.

96. Sun, Y.; Xia, Y. Shape-controlled synthesis of gold and silver nanoparticles. Science 2002, 298, 2176-2179. 
97. Kumar, D.; Karthik, L.; Kumar, G.; Roa, K.B. Biosynthesis of Silver anoparticles from Marine Yeast and Their Antimicrobial Activity Against Multidrug Resistant Pathogens. Pharmacologyonline 2011, 3, 1100-1111.

98. Dameron, C.T.; Reese, R.N.; Mehra, R.K.; Kortan, A.R.; Carroll, P.J.; Steigerwald, M.L.; Brus, L.E.; Winge, D.R. Biosynthesis of cadmium sulphide quantum semiconductor crystallites. Nature 1989, 338, 596-597.

99. Kowshik, M.; Deshmukh, N.; Vogel, W.; Urban, J.; Kulkarni, S.K.; Paknikar, K.M. Microbial synthesis of semiconductor $\mathrm{CdS}$ nanoparticles, their characterization, and their use in the fabrication of an ideal diode. Biotechnol. Bioeng. 2002, 78, 583-588.

100. Kowshik, M.; Ashtaputre, S.; Kulkani, S.K.; Parknikar, K.M.M. Extracellular synthesis of silver nanoparticles by a silver-tolerant yeast strain MKY3. Nanotechnology 2003, 14, 95-100.

101. Krumov, N.; Oder, S.; Perner-Nochta, I.; Angelov, A.; Posten, C. Accumulation of CdS nanoparticles by yeasts in a fed-batch bioprocess. J. Biotechnol. 2007, 132, 481-486.

102. Pimprikar, P.S.; Joshi, S.S.; Kumar, A.R.; Zinjarde, S.S.; Kulkarni, S.K. Influence of biomass and gold salt concentration on nanoparticle synthesis by the tropical marine yeast Yarrowia lipolytica NCIM 3589. Colloids Surf. B Biointerfaces 2009, 74, 309-316.

103. Tian, X.; He, W.; Cui, J.; Zhang, X.; Zhou, W.; Yan, S.; Sun, X.; Han, X.; Han, S.; Yue, Y. Mesoporous zirconium phosphate from yeast biotemplate. J. Colloid Interface Sci. 2010, 343, 344-349.

104. Yan, S.; He, W.; Sun, C.; Zhang, X.; Zhao, H.; Li, Z.; Zhou, W.; Tian, X.; Sun, X.; Han, X. The biomimetic synthesis of zinc phosphate nanoparticles. Dye Pigment 2009, 80, 254-258.

105. Fadeel, B.; Garcia-Bennett, A.E. Better safe than sorry: Understanding the toxicological properties of inorganic nanoparticles manufactured for biomedical applications. Adv. Drug Deliv. Rev. 2010, $62,362-374$.

106. Chan, W.C.W.; Nie, S. Quantum dot bioconjugates for ultrasensitive nonisotopic detection. Science 1998, 281, 2016-2018.

107. Tian, F.; Tian, F.; Prina-Mello, A.; Estrada, G.; Beyerle, A.; Möller, W.; Schulz, H.; Kreyling, W.; Stoeger, T. A novel assay for the quantification of internalized nanoparticles in macrophages. Nanotoxicology 2008, 2, 232-242.

108. Cui, D.; Tian, F.; Coyer, S.R.; Wang, J.; Pan, B.; Gao, F.; He, R.; Zhang, Y. Effects of Antisense-Myc-Conjugated Single-Walled Carbon Nanotubes on HL-60Cells. J. Nanosci. Nanotechnol. 2007, 7, 1639-1646.

109. Pantarotto, D.; Partidos, C.D.; Hoebeke, J.; Brown, F.; Kramer, E.D.; Briand, J.P.; Muller, S.; Prato, M.; Bianco, A. Immunization with peptide-functionalized carbon nanotubes enhances virus-specific neutralizing antibody responses. Chem. Biol. 2003, 10, 961-966.

110. De La Isla, A.; Brostow, W.; Bujard, B.; Estevez, M.; Rodriguez, J.R.; Vargas, S.; Castano, V.M. Nanohybrid scratch resistant coatings for teeth and bone viscoelasticity manifested in tribology. Mater. Res. Innov. 2003, 7, 110-114.

111. Ma, J.; Wong, H.; Kong, L.B.; Peng, K.W. Biomimetic processing of nanocrystallite bioactive apatite coating on titanium. Nanotechnology 2003, 14, 619.

112. Shinkai, M.; Yanase, M.; Suzuki, M.; Honda, H.; Wakabayashi, T.; Yoshida, J.; Kobayashi, T. Intracellular hyperthermia for cancer using magnetite cationic liposomes. J. Magn. Magn. Mater. 1999, 194, 176-184. 
113. Weissleder, R.; Elizondo, G.; Wittenberg, J.; Rabito, C.A.; Bengele, H.H.; Josephson, L. Ultrasmall superparamagnetic iron oxide: Characterization of a new class of contrast agents for MR imaging. Radiology 1990, 175, 489-493.

114. Parak, W.J.; Boudreau, R.; le Gros, M.; Gerion, D.; Zanchet, D.; Micheel, C.M.; Williams, S.C.; Alivisatos, A.P.; Larabell, C. Cell motility and metastatic potential studies based on quantum dot imaging of phagokinetic tracks. Adv. Mater. 2002, 14, 882-885.

115. Chaloupka, K.; Malam, Y.; Seifalian, A.M. Nanosilver as a new generation of nanoproduct in biomedical applications. Trends Biotechnol. 2010, 28, 580-588.

116. Emerich, D.F.; Thanos, C.G. The pinpoint promise of nanoparticle-based drug delivery and molecular diagnosis. Biomol. Eng. 2006, 23, 171-184.

117. Häfeli, U.O.; Riffle, J.S.; Harris-Shekhawat, L.; Carmichael-Baranauskas, A.; Mark, F.; Dailey, J.P.; Bardenstein, D. Cell uptake and in vitro toxicity of magnetic nanoparticles suitable for drug delivery. Mol. Pharm. 2009, 6, 1417-1428.

118. Vaidyanathan, R.; Kalishwaralal, K.; Gopalram, S.; Gurunathan, S. RETRACTED: NanosilverThe burgeoning therapeutic molecule and its green synthesis. Biotechnol. Adv. 2009, 27, 924-937.

119. Xiang, L.; Wei, J.; Jianbo, S.; Guili, W.; Feng, G.; Ying, L. Purified and sterilized magnetosomes from Magnetospirillum gryphiswaldense MSR-1 were not toxic to mouse fibroblasts in vitro. Lett. Appl. Microbiol. 2007, 45, 75-81.

120. Giljohann, D.A.; Seferos, D.S.; Daniel, W.L.; Massich, M.D.; Patel, P.C.; Mirkin, C.A. Gold nanoparticles for biology and medicine. Angew. Chemie Int. Ed. 2010, 49, 3280-3294.

121. Patra, C.R.; Bhattacharya, R.; Mukhopadhyay, D.; Mukherjee, P. Fabrication of gold nanoparticles for targeted therapy in pancreatic cancer. Adv. Drug Deliv. Rev. 2010, 62, 346-361.

122. Kalishwaralal, K.; Banumathi, E.; Pandian, S.R.K.; Deepak, V.; Muniyandi, J.; Eom, S.H.; Gurunathan, S. Silver nanoparticles inhibit VEGF induced cell proliferation and migration in bovine retinal endothelial cells. Colloids Surf. B: Biointerfaces 2009, 73, 51-57.

123. Chertok, B.; Moffat, B.A.; David, A.E.; Yu, F.; Bergemann, C.; Ross, B.D.; Yang, V.C. Iron oxide nanoparticles as a drug delivery vehicle for MRI monitored magnetic targeting of brain tumors. Biomaterials 2008, 29, 487-496.

124. Amarnath, K.; Mathew, N.L.; Nellore, J.; Siddarth, C.R.V.; Kumar, J. Facile synthesis of biocompatible gold nanoparticles from Vites vinefera and its cellular internalization against HBL-100 cells. Cancer Nanotechnol. 2011, 2, 121-132.

125. Jeyaraj, M.; Sathishkumar, G.; Sivanandhan, G.; MubarakAli, D.; Rajesh, M.; Arun, R.; Kapildev, G.; Manickavasagam, M.; Thajuddin, N.; Premkumar, K. Biogenic silver nanoparticles for cancer treatment: an experimental report. Colloids Surf. B Biointerfaces 2013, 106, 86-92.

126. Hsin, Y.H.; Chen, C.F.; Huang, S.; Shih, T.S.; Lai, P.S.; Chueh, P.J. The apoptotic effect of nanosilver is mediated by a ROS- and JNK-dependent mechanism involving the mitochondrial pathway in NIH3T3 cells. Toxicol. Lett. 2008, 179, 130-139.

127. Vamanu, C.I.; Cimpan, M.R.; Høl, P.J.; Sørnes, S.; Lie, S.A.; Gjerdet, N.R. Induction of cell death by $\mathrm{TiO}_{2}$ nanoparticles: Studies on a human monoblastoid cell line. Toxicol. In Vitro 2008, 22, 1689-1696.

128. Park, E.J.; Yi, J.; Chung, K.H.; Ryu, D.Y.; Choi, J.; Park, K. Oxidative stress and apoptosis induced by titanium dioxide nanoparticles in cultured BEAS-2B cells. Toxicol. Lett. 2008, 180, 222-229. 
129. Zhao, J.; Bowman, L.; Zhang, X.; Vallyathan, V.; Young, S.H.; Castranova, V.; Ding, M. Titanium dioxide $\left(\mathrm{TiO}_{2}\right)$ nanoparticles induce JB6 cell apoptosis through activation of the caspase-8/Bid and mitochondrial pathways. J. Toxicol. Environ. Heal. Part A 2009, 72, 1141-1149.

130. Huang, D.M.; Chung, T.H.; Hung, Y.; Lu, F.; Wu, S.H.; Mou, C.Y.; Yao, M.; Chen, Y.C. Internalization of mesoporous silica nanoparticles induces transient but not sufficient osteogenic signals in human mesenchymal stem cells. Toxicol. Appl. Pharmacol. 2008, 231, 208-215.

131. Zhu, Y.; Eaton, J.W.; Li, C. Titanium Dioxide $\left(\mathrm{TiO}_{2}\right)$ Nanoparticles Preferentially Induce Cell Death in Transformed Cells in a Bak/Bax-Independent Fashion. PLoS ONE 2012, 7, 1-11.

132. Nishida, N.; Yano, H.; Nishida, T.; Kamura, T.; Kojiro, M. Angiogenesis in cancer. Vasc. Health Risk Manag. 2006, 2, 213-219.

133. Ghosh, P.; Han, G.; De, M.; Kim, C.K.; Rotello, V.M. Gold nanoparticles in delivery applications. Adv. Drug Deliv. Rev. 2008, 60, 1307-1315.

134. Will, S.E.A.; Favaron, P.O.; Pavez, M.A.; Florentino, L.C.; Soares, D.; Oliveira, F.C.; Rici, R.E.G.; Miglino, M.A.; Alcântara, D.; Mamizuka, E.M. Bactericidal silver nanoparticles present an antiangiogenic effect in the Chorioallantoic Membrane Model (CAM). Sci. Against Microb. Pathog. Commun. Curr. Res. Technol. Adv. 2011, 1, 219-227.

135. Gurunathan, S.; Lee, K.-J.; Kalishwaralal, K.; Sheikpranbabu, S.; Vaidyanathan, R.; Eom, S.H. Antiangiogenic properties of silver nanoparticles. Biomaterials 2009, 30, 6341-6350.

136. Sheikpranbabu, S.; Kalishwaralal, K.; Venkataraman, D.; Eom, S.H.; Park, J.; Gurunathan, S. Silver nanoparticles inhibit VEGF-and IL-1-beta-induced vascular permeability via Src dependent pathway in porcine retinal endothelial cells. J. Nanobiotechnol. 2009, 7, doi:10.1186/1477-3155-7-8.

137. Mohammadzadeh, R. Hypothesis: Silver nanoparticles as an adjuvant for cancertherapy. Adv. Pharm. Bull. 2012, 2, doi:10.5681/apb.2012.020.

138. Durán, N.; Marcato, P.D.; de Souza, G.I.H.; Alves, O.L.; Esposito, E. Antibacterial effect of silver nanoparticles produced by fungal process on textile fabrics and their effluent treatment. J. Biomed. Nanotechnol. 2007, 3, 203-208.

139. Gajbhiye, M.; Kesharwani, J.; Ingle, A.; Gade, A.; Rai, M. Fungus-mediated synthesis of silver nanoparticles and their activity against pathogenic fungi in combination with fluconazole. Nanomed. Nanotechnol. Biol. Med. 2009, 5, 382-386.

140. Bankar, A.; Joshi, B.; Kumar, A.R.; Zinjarde, S. Banana peel extract mediated synthesis of gold nanoparticles. Colloids Surf. B Biointerfaces 2010, 80, 45-50.

141. Zheng, D.; Hu, C.; Gan, T.; Dang, X.; Hu, S. Preparation and application of a novel vanillin sensor based on biosynthesis of Au-Ag alloy nanoparticles. Sens. Actuators B Chem. 2010, 148, 247-252.

142. Zheng, B.; Qian, L.; Yuan, H.; Xiao, D.; Yang, X.; Paau, M.C.; Choi, M.M.F. Preparation of gold nanoparticles on eggshell membrane and their biosensing application. Talanta 2010, 82, 177-183.

143. Iskandar, F. Nanoparticle processing for optical applications-A review. Adv. Powder Technol. 2009, 20, 283-292.

144. Zhu, T.; Cloutier, S.G.; Ivanov, I.; Knappenberger, K.L.; Robel, I.; Zhang, F. Nanocrystals for electronic and optoelectronic applications. J. Nanomater. 2012, 2012, doi:10.1155/2012/392742.

145. Sarkar, R.; Kumbhakar, P.; Mitra, A.K. Green synthesis of silver nanoparticles and its optical properties. Dig. J. Nanomater. Biostruct. 2010, 5, 491-496. 
146. Podgaetsky, V.M.; Tereshchenko, S.A.; Reznichenko, A.V.; Selishchev, S.V. Laser-limiting materials for medical use. In Optical Technologies for Industrial, Environmental, and Biological Sensing; International Society for Optics and Photonics: Bellingham, WA, USA, 2004; pp. 183-191.

147. Bao, H.; Hao, N.; Yang, Y.; Zhao, D. Biosynthesis of biocompatible cadmium telluride quantum dots using yeast cells. Nano Res. 2010, 3, 481-489.

148. Bao, H.; Lu, Z.; Cui, X.; Qiao, Y.; Guo, J.; Anderson, J.M.; Li, C.M. Extracellular microbial synthesis of biocompatible CdTe quantum dots. Acta Biomater. 2010, 6, 3534-3541.

(C) 2015 by the authors; licensee MDPI, Basel, Switzerland. This article is an open access article distributed under the terms and conditions of the Creative Commons Attribution license (http://creativecommons.org/licenses/by/4.0/). 